\title{
GEOTECHNICAL ASPECTS OF THE 2016 KAIKŌURA EARTHQUAKE ON THE SOUTH ISLAND OF NEW ZEALAND
}

\author{
Mark E. Stringer ${ }^{1}$, Sarah Bastin ${ }^{2}$, Christopher R. McGann', \\ Claudio Cappellaro ${ }^{2}$, Maya El Kortbawi ${ }^{3}$, Rebecca McMahon ${ }^{4}$, \\ Liam. M. Wotherspoon ${ }^{4}$, Russell A. Green ${ }^{3}$, Jason Aricheta ${ }^{4}$, \\ Ross Davis ${ }^{5}$, Leigh McGlynn ${ }^{5}$, Sally Hargraves ${ }^{6}$, \\ Sjoerd van Ballegooy ${ }^{7}$, Misko Cubrinovski ${ }^{2}$, \\ Brendon A. Bradley ${ }^{2}$, Xavier Bellagamba ${ }^{2}$, Kevin Foster ${ }^{2}$, \\ Carlo Lai ${ }^{8}$, Dan Ashfield ${ }^{7}$, Abdul Baki ${ }^{2}$, Adda Zekkos9, \\ Robin Lee ${ }^{2}$ and Nikolaos Ntritsos ${ }^{2}$
}

(Submitted March 2017; Reviewed April 2017; Accepted May 2017)

\begin{abstract}
The magnitude Mw7.8 'Kaikōura' earthquake occurred shortly after midnight on 14 November 2016. This paper presents an overview of the geotechnical impacts on the South Island of New Zealand recorded during the postevent reconnaissance.

Despite the large moment magnitude of this earthquake, relatively little liquefaction was observed across the South Island, with the only severe manifestation occurring in the young, loose alluvial deposits in the floodplains of the Wairau and Opaoa Rivers near Blenheim. The spatial extent and volume of liquefaction ejecta across South Island is significantly less than that observed in Christchurch during the 2010-2011 Canterbury Earthquake Sequence, and the impact of its occurrence to the built environment was largely negligible on account of the severe manifestations occurring away from the areas of major development.
\end{abstract}

Large localised lateral displacements occurred in Kaikōura around Lyell Creek. The soft fine-grained material in the upper portions of the soil profile and the free face at the creek channel were responsible for the accumulation of displacement during the ground shaking. These movements had severely impacted the houses which were built close (within the zone of large displacement) to Lyell Creek. The wastewater treatment facility located just north of Kaikoura also suffered tears in the liners of the oxidation ponds and distortions in the aeration system due to ground movements.

Ground failures on the Amuri and Emu Plains (within the Waiau Valley) were small considering the large peak accelerations (in excess of $1 \mathrm{~g}$ ) experienced in the area. Minor to moderate lateral spreading and ejecta was observed at some bridge crossings in the area. However, most of the structural damage sustained by the bridges was a result of the inertial loading, and the damage resulting from geotechnical issues were secondary.

\section{INTRODUCTION}

This paper presents a detailed overview of the impacts from liquefaction and related phenomena on the South Island of New Zealand resulting from the 2016, Mw7.8 Kaikōura earthquake. The Kaikōura earthquake began at 12:02:56 am on the 14th November 2016 on the South Island of New Zealand and involved a series of fault ruptures (shown on Figure 1) which propagated in a roughly north easterly direction. Strong motion recordings indicate very high peak ground accelerations occurred in the Waiau Valley of North Canterbury (marked "Area C" in Figure 1). Horizontal accelerations at the Waiau strong motion station (WTMC) were in excess of $1 \mathrm{~g}$ and vertical accelerations in excess of
$2.7 \mathrm{~g}$. The ground motions were significantly attenuated in the main urban areas of the South Island; in the areas around Blenheim (Area A) and Kaikōura (Area B), the recorded peak ground accelerations were in the range of $0.14 \mathrm{~g}$ to $0.27 \mathrm{~g}$. A more detailed summary of the ground motion characteristics across the South Island is provided in Bradley et al. [1].

In the days and weeks following the earthquake, a collaborative approach was taken to the reconnaissance across the South Island, and involved New Zealand based researchers and practicing engineers, as well as visiting academics and members of the Geotechnical Extreme Events Reconnaissance Association (GEER). Reconnaissance was undertaken in 3 phases; in the days following the earthquake, exploratory

${ }^{1}$ Corresponding Author, Lecturer, Civil and Natural Resources Engineering, University of Canterbury mark.stringer@canterbury.ac.nz (Member)

2 University of Canterbury, Christchurch, NZ

3 Virginia Tech, USA

${ }^{4}$ University of Auckland, $N Z$

${ }^{5}$ Davidson Group

${ }^{6}$ Terra Firma Engineering

7 Tonkin and Taylor Ltd, NZ

8 University of Pavia, Italy

9 University of Michigan, USA 
missions were undertaken to define broad areas where earthquake related damage had occurred. Additional field surveys were undertaken in the areas marked $\mathrm{A}$ to $\mathrm{C}$ in Figure 1 between 17th November and 11th December 2016 first to record perishable data (such as evidence of liquefaction, lateral spreading and damage to structures) and later to characterise specific sites.

Given the geographic distribution of the varying geologic settings, liquefaction hazard, and ground motions, each of the four areas shown in Figure 1 are presented separately in subsequent sections of this paper in order of north to south. In the area of Blenheim, severe liquefaction and lateral spreading occurred on the flood plains of the Wairau River, particularly on inner meander bends and locations of paleo features. In Kaikōura, a series of localised failures in soft soil deposits caused large lateral displacements along Lyell Creek and caused damage to a number of houses built within $30 \mathrm{~m}$ of the creek. Despite the extreme ground motions recorded close to the town of Waiau, relatively little evidence of liquefaction was observed, and the main impacts in this area were to the bridges, many of which showed severe structural distress. Detailed reconnaissance in Christchurch (Area D) was not carried out, though observations from four sites in the city and towns to the north are briefly discussed.

It is important to state that while a number of examples of damage are presented in this paper, the most significant impacts of the 2016 Kaikoura earthquake arose from the numerous landslides across the South Island (which cut off the town of Kaikōura, as well as blocking and severely damaging the N-S highway and railway), and the damage which was sustained at Wellington's CentrePort facility. These aspects are outside the scope of this paper. Landslide and fault ruptures on the South Island are discussed in Dellow et al. [2] and Stirling et al. [3] respectively. Impacts of liquefaction on the North Island (which includes the CentrePort facility) are presented in Cubrinovski et al. [4].

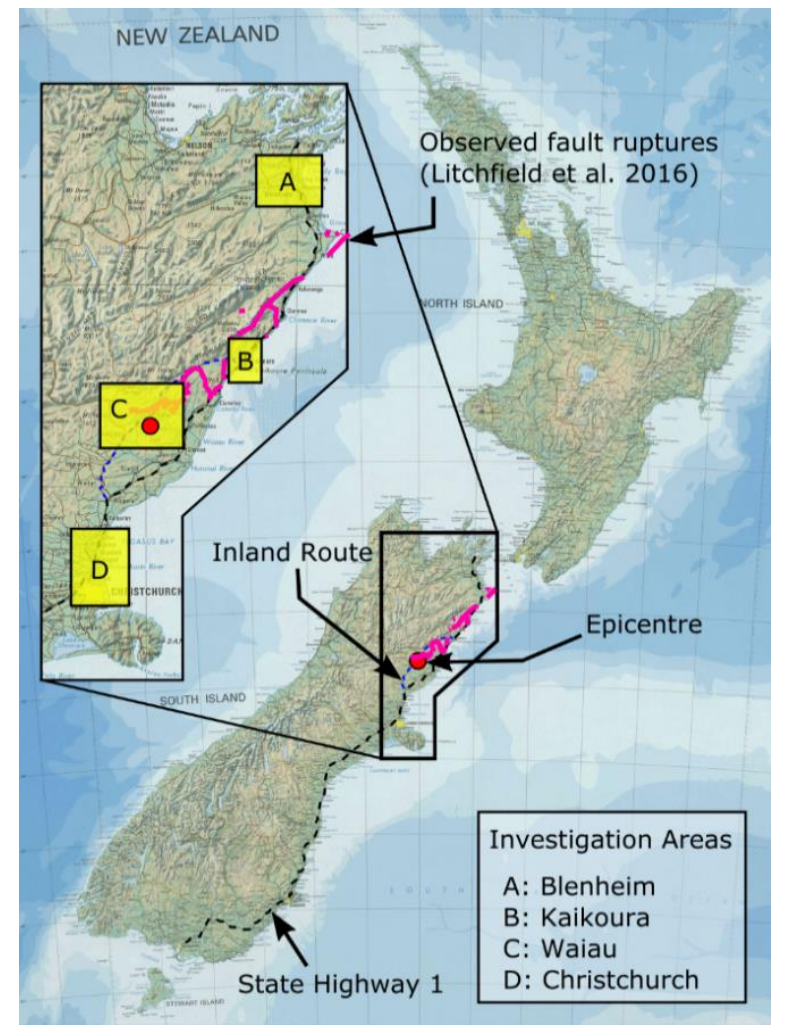

Figure 1: Location of main reconnaissance areas. Dashed lines indicate road routes outside of these main areas that were also surveyed by reconnaissance teams.

\section{GEOLOGIC BACKGROUND AND HISTORIC SEISMICITY OF THE MARLBOROUGH FAULT ZONE}

The Kaikoura earthquake was centred within the Marlborough Fault Zone (MFZ); a zone of active faulting which marks the transition of the Australian and Pacific plate boundary from oblique continent-to-continent collision within the central South Island, to offshore subduction. Plate motion is primarily accommodated through four major NE trending transpressive dextral strike-slip faults namely the Waiau, Awatere, Clarence, and Hope Faults. Compressional uplift along the faults results in a series of north-east trending mountain ranges separated by wide valleys. Rivers generally traverse the fault trace at the base of the ranges and are strongly influenced by fault movements. A zone of active faulting and folding continues to the south of the Hope Fault and includes the Hundalee Fault and Humps Fault Zone [5] which ruptured during the Kaikōura earthquake.

The MFZ is one of the most tectonically active regions of New Zealand with many shallow earthquakes documented in the region since initial European settlement. Two large earthquakes with magnitudes greater than 7.0, and six shallow earthquakes with magnitudes 6.0-6.9 have been recorded in the MFZ post-European settlement in $\sim 1840$ [6]. The 1848 $\sim$ M7.5 Marlborough earthquake ruptured $\sim 100 \mathrm{~km}$ of the Awatere Fault and caused extensive regional shaking and damage to buildings [7]. Liquefaction was reported proximal the Wairau, Awatere, and Clarence Rivers [6]. The 1888 $\sim$ M7.0-7.3 North Canterbury earthquake ruptured a $30 \pm 5 \mathrm{~km}$ segment of the Hope Fault, resulting in a narrow zone of extensive building damage parallel to the rupture trace and widespread contents damage within the central South Island [8]. No historical accounts of liquefaction are documented though it is possible that localised liquefaction occurred within susceptible sediments and went unreported due to the rural nature of the area. Other damaging earthquakes include the 1901 M6.9 Cheviot earthquake, and the 1922 M6.4 Motunau earthquake, both of which caused widespread damage within North Canterbury. The $1948 \sim$ M6.4 Waiau earthquake also caused minor structural damage in Hanmer and Waiau [9]. The Cheviot earthquake triggered widespread liquefaction within susceptible sediments in North Canterbury, while no reports of liquefaction have been found for the Motunau or Waiau earthquakes [9]. More recently the $2013 \mathrm{M}_{\mathrm{w}} 6.5$ Cook Strait earthquake, centred $25 \mathrm{~km}$ east of Seddon, and the $M_{w} 6.6$ Lake Grassmere earthquake, located $30 \mathrm{~km}$ south-east of Blenheim, caused moderate damage to land and infrastructure near the source region, including triggering liquefaction within the township of Blenheim [10].

\section{BLENHEIM AND THE WAIRAU PLAIN}

The township of Blenheim is located on the north-eastern corner of the South Island, New Zealand (Location A in Figure 1), with a population of around 30,000 in the main urban area [11]. The town is located $\sim 5 \mathrm{~km}$ from the coast within the relatively flat Wairau Plain and is situated on Holocene swamp deposits composed of poorly consolidated silt, mud, peat and sand. East of the township, the soils are comprised of Holocene alluvial silts and sands, interlayered with coastal sand, silt and gravel. A number of rivers are present in the Wairau Valley including the braided Wairau River to the north of the township, as well as the spring fed Taylor and Opaoa (previously named Opawa) Rivers, which today flow through the urban area of Blenheim. The braided Wairau River transitions into a meandering regime approximately $4 \mathrm{~km}$ from the coastline, and it is important to note that the main flow of the river was diverted away from its meandering section and towards the coast [12] in the 1960s to reduce flooding within the township (Figure 2). The natural 
system of rivers in and around the town of Blenheim has been significantly altered by the effects of river channelization and diversion, as well as the construction of stopbanks and attempts to drain the swamps throughout the development of the town. These effects have resulted in many paleo channels within the area of the Blenheim township. It is interesting to note that there are many similarities between the geologic settings of Blenheim and Christchurch, particularly the alluvial depositional environment, as well as the presence of swamps cross-cut by small river channels [13].

Two ground motion stations are present within the Wairau Valley, as shown on Figure 2. At the MCGS station within Blenheim (Site Class D according to NZS1170.5 [14]), the geometric mean of the peak ground accelerations (PGA) of the two horizontal components of motion was $0.22 \mathrm{~g}$. Further north at the BWRS strong motion station, situated on rock (Site Class B) at the base of the hills, the geometric mean PGA was $0.14 \mathrm{~g}$. Approximately $20 \mathrm{~km}$ southeast of Blenheim, geometric mean PGA of $0.66 \mathrm{~g}$ was recorded at the SEDS station (Site Class D) in the town of Seddon (Station SEDS on the edge of the Awatere Valley. Note both the relatively small number of strong motion stations in the area (implying high uncertainty in the demand across the area), as well as the variation in PGA between the stations which indicate decreasing PGA within the Wairau valley. It is also interesting to note that similar PGAs as those recorded in Blenheim were estimated to have occurred in the red zone of Christchurch during the September 2010 Darfield earthquake [15].

Reconnaissance in the Blenheim area took place in two phases; initial exploratory visits were undertaken between the $17^{\text {th }}$ and $19^{\text {th }}$ November and aimed to discover the extent of damage. A few sites were targeted based on media reports, as well as information from locals and engineers, but areas likely to experience significant amounts of damage (such as along rivers) were also investigated. Observations were made as far south as Ward, though it should be noted that south of Blenheim this reconnaissance was limited and very few sites were investigated. Additional reconnaissance work was

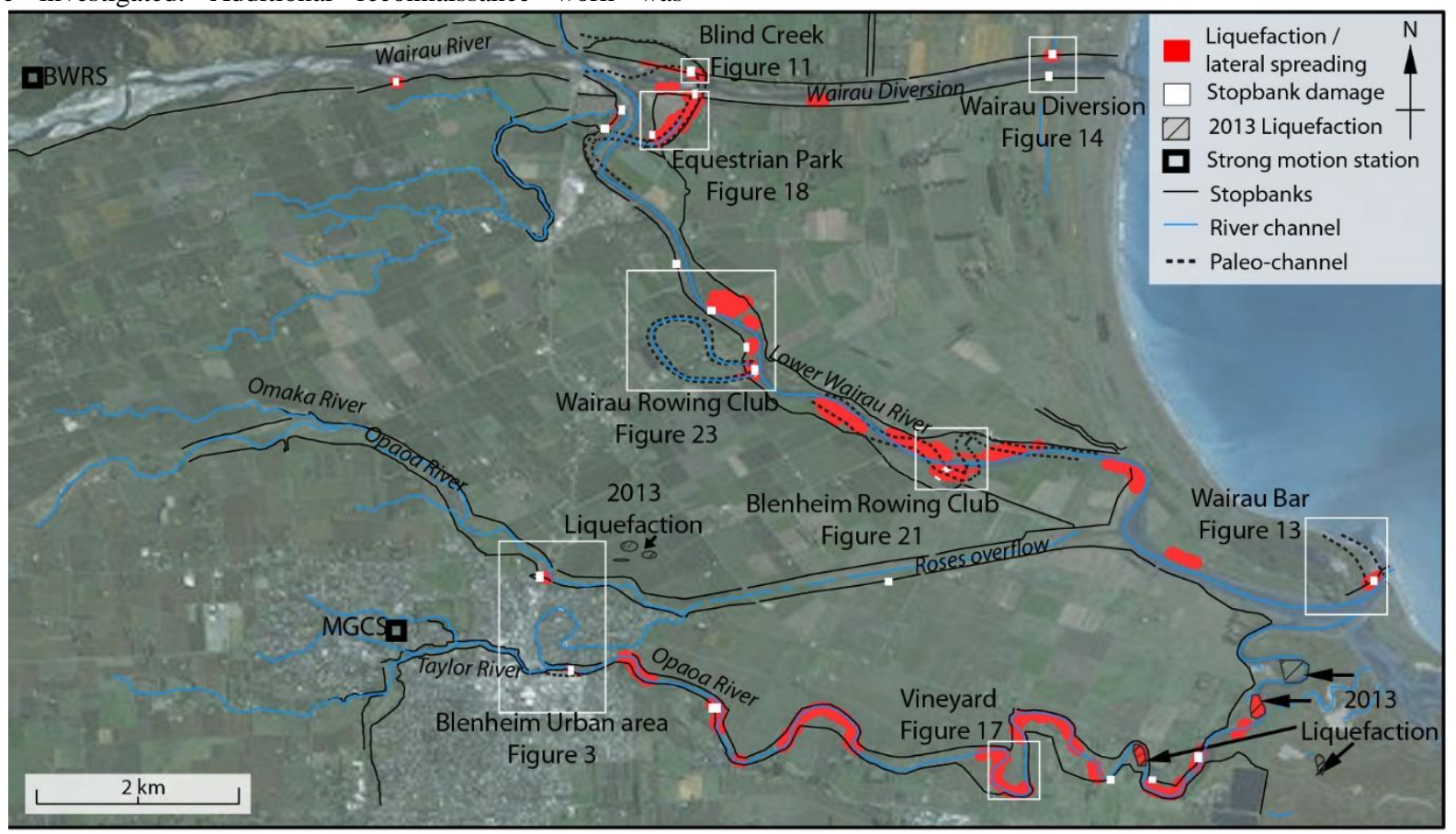

Figure 2: Overview of liquefaction damage in Blenheim and the Wairau Plains resulting from the $2016 M_{w} 7.8$ Kaikoura earthquake and $2013 M_{w} 6.6$ Lake Grassmere earthquake (Approx. coord. of centre of image: $-41.495^{\circ}, 173.980^{\circ}$ ). carried out in the Blenheim area between $4^{\text {th }}$ and $7^{\text {th }}$ December 2016 and focussed on sites that had been previously visited with the aim of gathering information relevant to site characterisation.

The reconnaissance surveys, aerial photography, and discussions with local engineers and the Marlborough District Council provided a comprehensive summary of the liquefaction related impacts and manifestations in the Blenheim area. Thus, the damage depicted in Figure 2 is considered to give a complete representation of the liquefaction-related damage in the area.

Within the Wairau Valley, liquefaction and lateral spreading was the major feature of ground damage, and was largely observed along the Lower Wairau and Opaoa Rivers. Severe manifestations of liquefaction were recorded in the area of the Equestrian Park and the Blenheim Rowing Club however, very few buildings are present in these areas, and the engineering impact was generally low. It is also important to note that despite the very loose nature of these deposits, the extent and quantity of ejecta is significantly less than what was observed in either of the 2010 Darfield or 2011 Christchurch Earthquakes [16, 17]. Some moderate liquefaction was observed in a few locations within the township of Blenheim, but these locations were either along the river or in the area of the sports fields at the north of the town and had limited impact on infrastructure.

Liquefaction and lateral spreading was observed within the area during historic earthquakes. For example, liquefaction and lateral spreading was documented on the Wairau Plains as well as the Awatere and Clarence Valleys to the south during the Mw7.5 1848 Marlborough earthquake and the Mw8.2 1855 Wairarapa earthquake [7, 18, 19], while van Dissen et al [10] reported liquefaction and lateral spreading around the Opaoa River and Wairau Lagoon (shown in Figure 2) during the Mw6.6 2013 Lake Grassmere earthquake. 


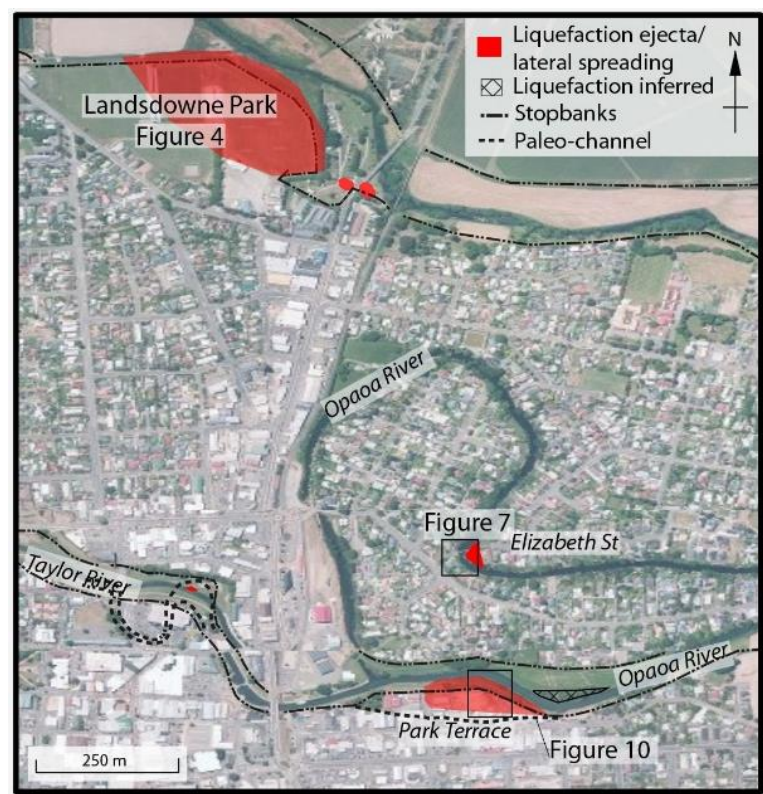

Figure 3: Overview of liquefaction related damage within the Blenheim urban area (Approx. coord. of centre of image: $\left.-41.507^{\circ}, 173.962^{\circ}\right)$.

\section{Liquefaction Impacts in the Blenheim Urban Area during the Kaikōura Earthquake}

Localised liquefaction and associated lateral spreading occurred during the Kaikoura earthquake proximal to the Opaoa River within Blenheim as outlined in Figure 3. Liquefaction and lateral spreading related damage was confined to the inner-banks of meander bends of the rivers or was associated paleo-channels; no damage was observed on the outer-banks of the meander bends. Localised liquefaction also occurred adjacent to the Taylor River within central Blenheim, in an area that was formerly within the river channel prior to modification and straightening in 1969 which subsequently reduced flow levels (Figure 3 [20]).

Sand boils were observed at Lansdowne Park which is located adjacent to the southern bank of the Opaoa River on the northern edge of Blenheim (Figure 3 and Figure 4). Test pits and cone penetration tests (CPT) were performed at locations marked in Figure 4 approximately 6 weeks prior to the Kaikoura earthquake to characterise the soils in the SE portion of the map shown in Figure 4. The test pits indicated between 1.5 and $2 \mathrm{~m}$ of silts and silty sands, below which is sandy silty gravel. The CPTs indicate that this gravelly layer ( $\mathrm{q}_{\mathrm{c} 1 \mathrm{~N}}$ typically around 400 , and $I_{c}$ rapidly transitioning in the range 0.8-1.5) has a thickness of between $3-5 \mathrm{~m}$.

A detailed survey of ejecta was conducted in the southern half of Lansdowne Park; the location of ejecta features are shown in red in Figure 4. Sand boils were typically 1-2 $\mathrm{m}$ in diameter and in many cases formed lineaments of aligned sand boils (Figure 5). The ejecta material was largely bluish-grey in colour, but there were some features which were light brown in colour. No liquefaction ejecta was observed adjacent to the main stadium buildings; a single crack in the concrete foundation slab was the only observable damage (Figure 5b).

Wet sieve analyses (carried out in general accordance with ASTM D422-63 [21]) were performed on 10 ejecta specimens from across Lansdowne Park (locations are marked in Figure 4 with blue stars). The particle size distributions (PSD), which are summarised in Figure 6, can be separated into two groupings, LDP-3, 5, 8, 9 and 10 being relatively similar fine sands, while the samples LDP-1, 2, 4, 6 and 7 were medium sands.

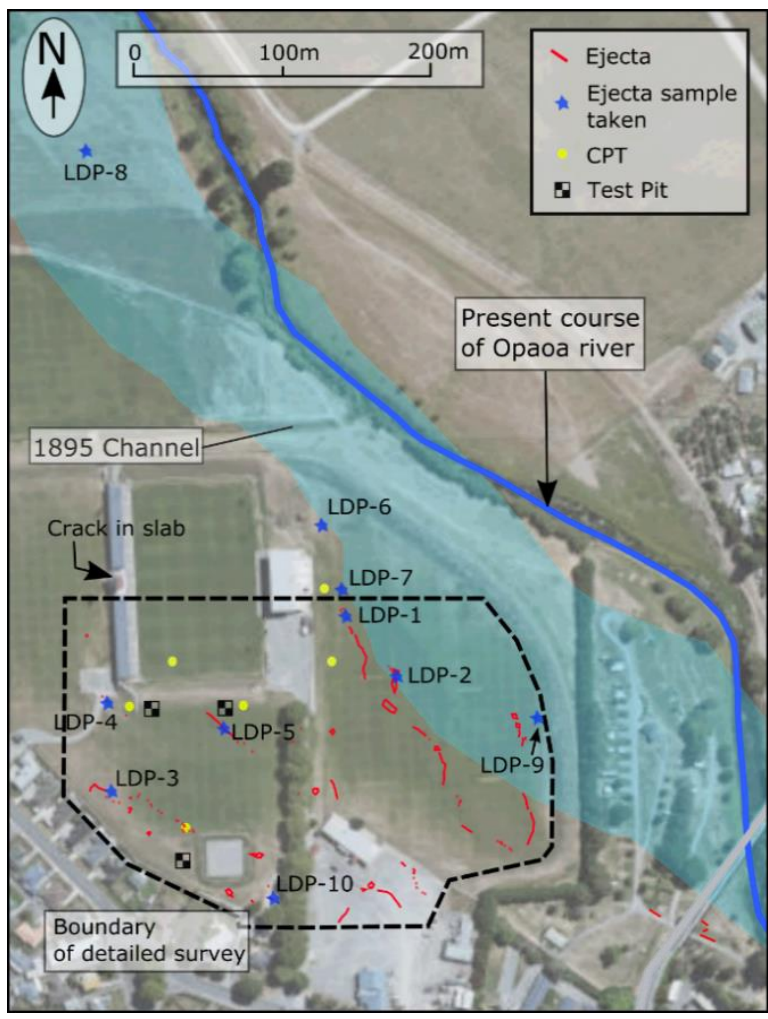

Figure 4: Ejecta deposits mapped within Lansdowne Park shown by red areas, and their relationship to the position of the 1895 channel of the Opaoa (Opawa) River (Approx. coord. of centre of image: $-41.498^{\circ}, 173.958^{\circ}$ ).

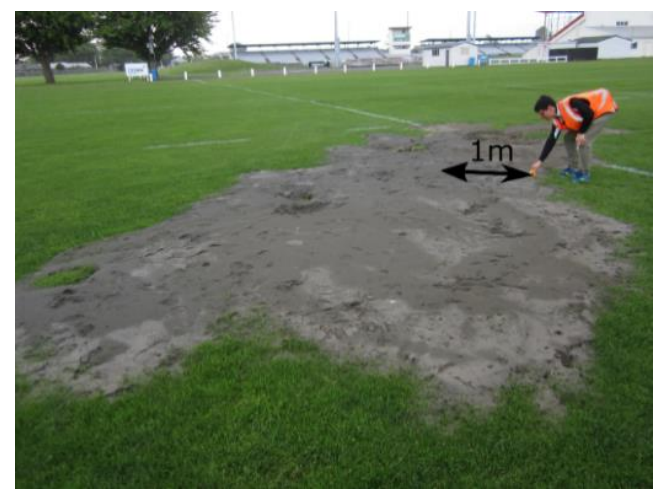

(a)

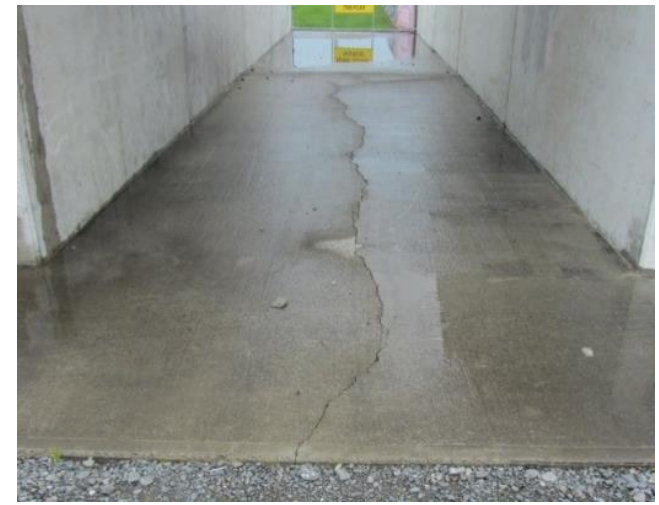

(b)

Figure 5: Ground damage observations at Lansdowne Park: (a) Example of liquefaction ejecta features observed at Lansdowne Park $\left(-41.4996^{\circ}, 173.959^{\circ}\right.$, taken facing $\left.W\right)$; (b) cracking of stadium foundation slab $\left(-41.4993^{\circ}\right.$, $173.9569^{\circ}$, taken facing $E$ ). 


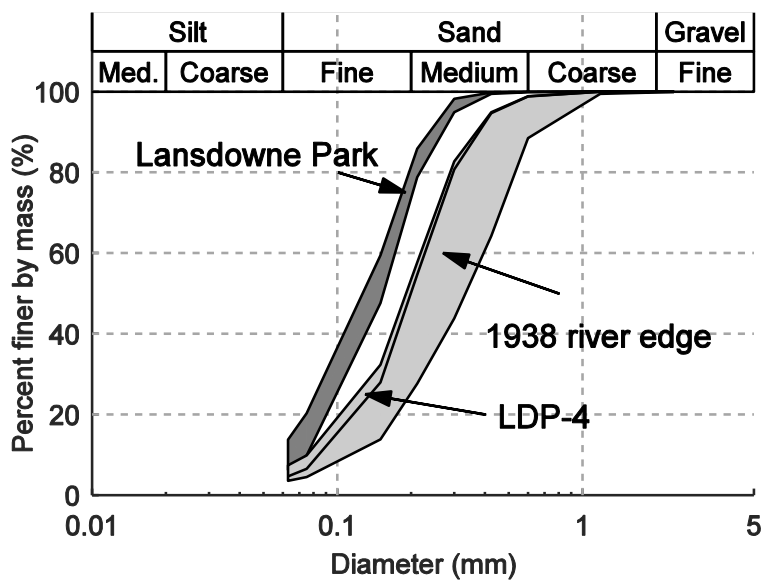

Figure 6: Particle size distributions of the ejecta obtained from Lansdowne Park.

Historical maps from 1895 [22] indicate that the Opaoa River formerly flowed across the northeast part of Lansdowne Park (1895 river channel is shown in blue in Figure 4). It is apparent that, with the exception of LDP-4, the samples of ejecta classified as medium sands fall along the edge of this river channel. The other liquefaction features either fall within the old river channels, or in the flood plain to the west of the 1895 river channel. It should be noted that additional liquefaction features were discovered outside the boundary of the detailed survey. However, the distribution of features was not mapped in detail with only the location of ejecta samples indicated. Additional liquefaction ejecta features were discovered within paleo-channels in the former flood plain to the west of the park, while lateral spreading and grey sand ejecta were observed to the east. These features also align with the 1895 river channel. The occurrence of liquefaction and lateral spreading in paleo channels is common and was observed in the 2011 Christchurch earthquake, where paleo channels running through the city caused localised damage and manifestations of liquefaction [17].

Lateral spreading was observed adjacent to an inner-bank of a meander loop of the Opaoa River at the western end of Elizabeth Street, downstream from Lansdowne Park (location shown in Figure 3). The lateral spreading extended approximately $30 \mathrm{~m}$ from the river channel on the inner meander bend, with cumulative displacements (based on crack widths) of $0.5-0.7 \mathrm{~m}$. Lateral spreading induced cracks were orientated approximately parallel to the riverbanks on both sides of the apex of meander bend. On the inner meander bend, the ground is steeply sloped within $5 \mathrm{~m}$ of the river channel, and a series of cracks perpendicular to the river bank were present in this zone. Individual cracks had widths up to $500 \mathrm{~mm}$ wide, with vertical displacements across the cracks of up to $100 \mathrm{~mm}$ and depths of up to $1 \mathrm{~m}$. Cracks near the river's edge were infilled with blueish grey fine-medium sand ejecta and extended through the eastern end of the adjacent footbridge (Figure 7a).

The lateral spreading affected the house on the inside of the meander bend (Figure $7 \mathrm{~b}$ ). The house was subsequently deemed unsafe for permanent occupancy due to the differential movement and settlement; this was the only house in Blenheim deemed unsafe to occupy due to liquefaction related damage. The lateral spreading displacements affected the footbridge at this location, causing the wooden deck to warp as the abutment displaced towards the river by approximately $0.5 \mathrm{~m}$.
The log from a hand auger performed adjacent to the river indicates that the soil profile is comprised of a light brown silt with some sand to a depth of $1.2 \mathrm{~m}$, underlain by fine blueish grey sand to $1.4 \mathrm{~m}$, and blueish grey fine-medium sand below that, with the water table at a depth of $1 \mathrm{~m}$. Proximal to the house the water table was at a depth of $2 \mathrm{~m}$, with the bluish grey fine-medium sand encountered at $2.4 \mathrm{~m}$ depth. The ejecta were uniformly composed of grey fine-medium sand, and the PSD of these ejecta are shown in Figure 8. Also shown in this figure is the PSD of samples taken from the Taylor River, which has similar fines content and general characteristics as the Elizabeth Street samples.

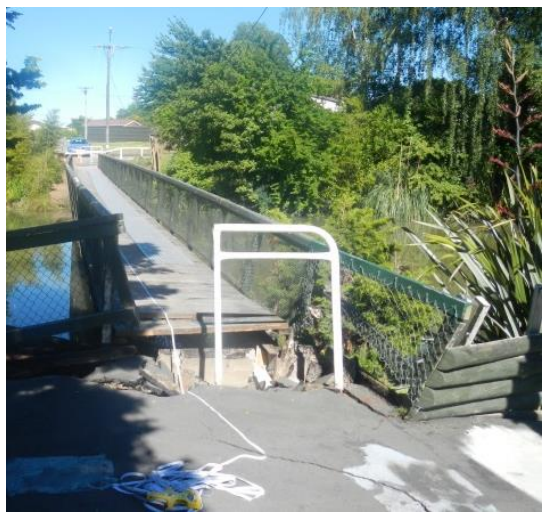

(a)

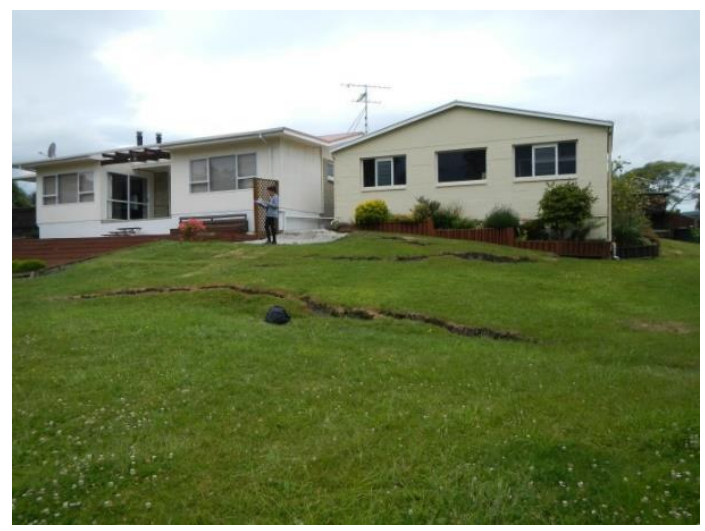

(b)

Figure 7: Damage at Elizabeth Street as a result of lateral spreading: (a) Damage to the footbridge $\left(-41.5087^{\circ}\right.$,

$173.9636^{\circ}$, taken facing WSW); (b) damage to residential property $\left(-41.5089^{\circ}, 173.9636^{\circ}\right.$, taken facing $\left.E\right)$.

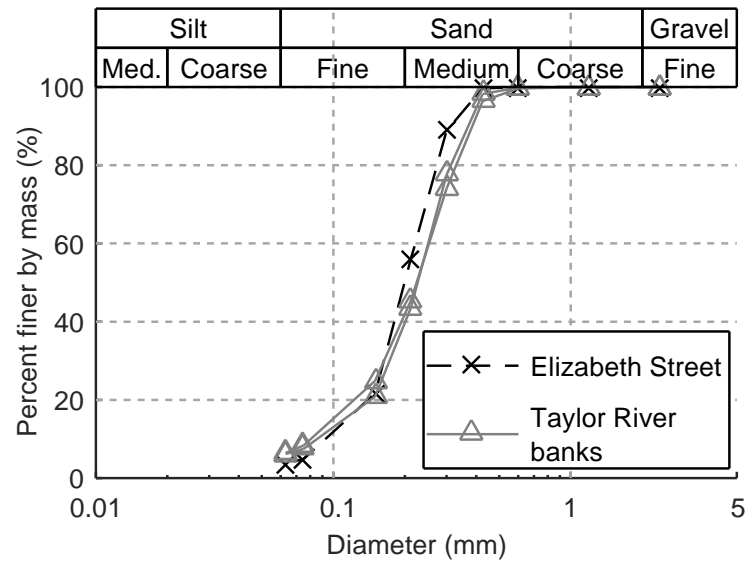

Figure 8: Particle size distribution of ejecta samples in the Blenheim CBD area (Taylor River: TR-1 \& TR-2 and Elizabeth Street: $E C-1)$. 


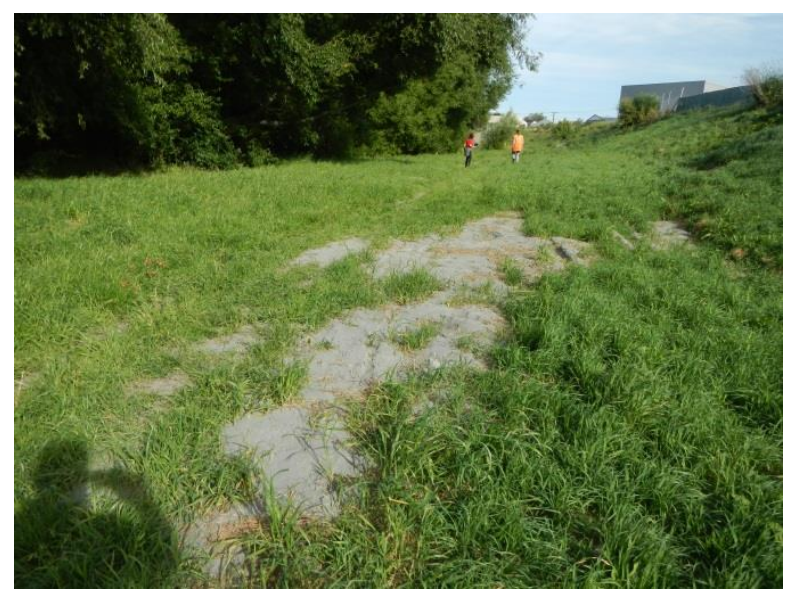

(a)

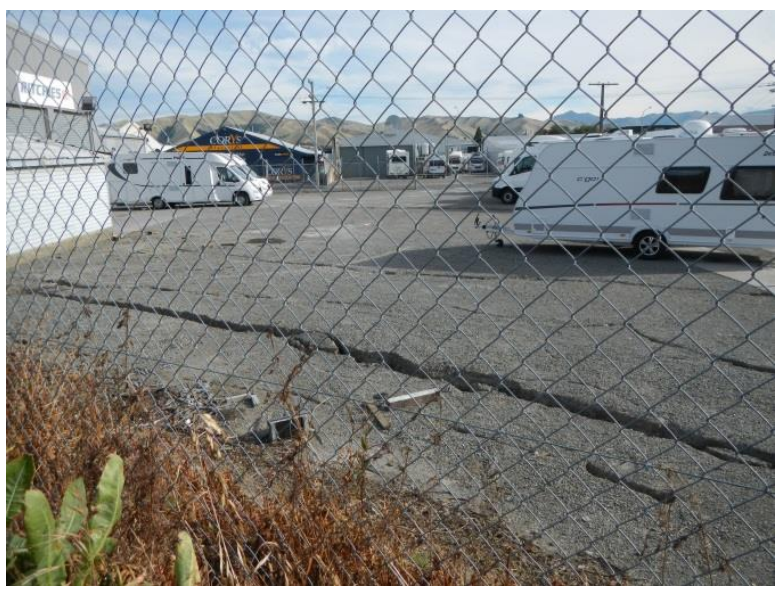

(b)

Figure 9: a) Example of liquefaction ejecta proximal to the river bank at the base of the stop bank $\left(-41.5121^{\circ}, 173.9651^{\circ}\right.$, taken facing SE); b) Example of damage to properties on Park Terrace as a result of lateral spreading $\left(-41.5122^{\circ}, 173.9649^{\circ}\right.$, taken facing $S$ ).

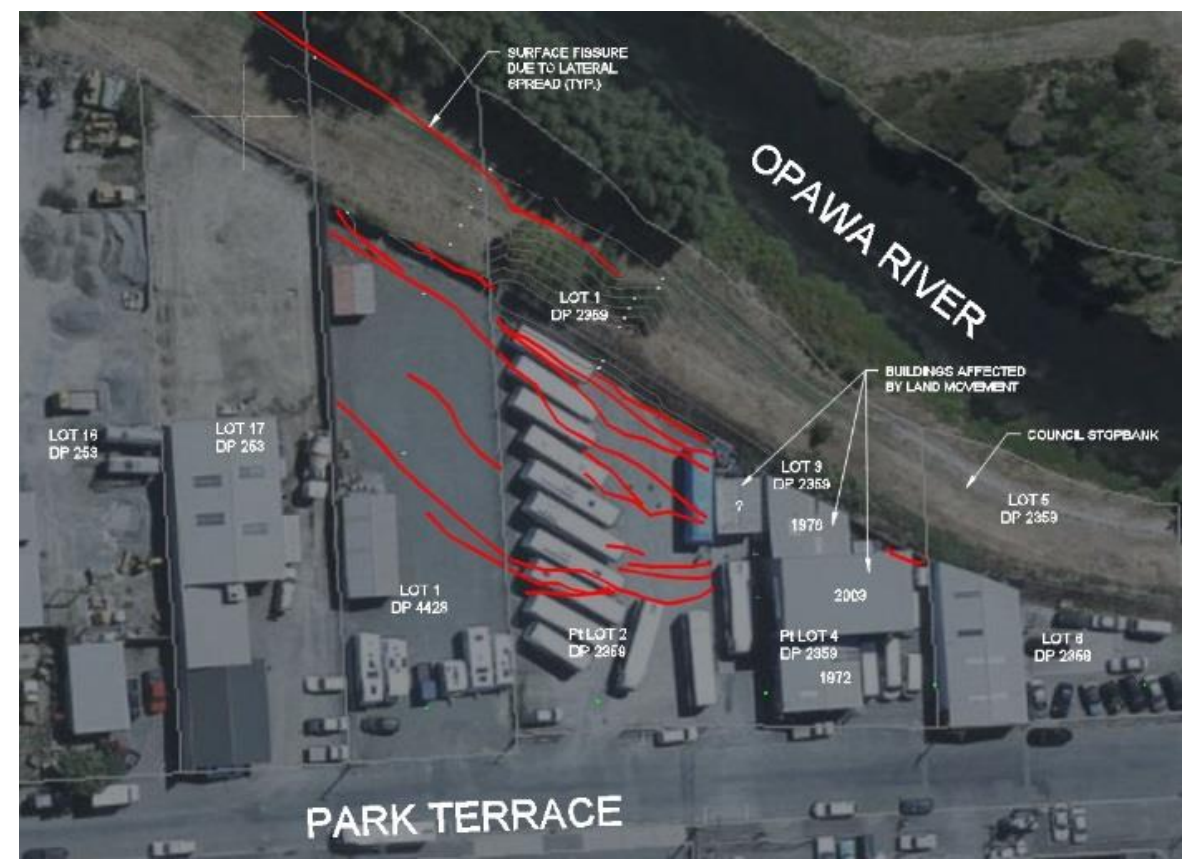

Figure 10: Summary of liquefaction manifestations at the Park Terrace site (Approx. coord. of centre of image: $-41.5123^{\circ}$, $173.9650^{\circ}$ ).

Moderate volumes of liquefaction ejecta and lateral spreading was observed at the inner-meander bend of the Opaoa River north of Park Terrace, just downstream from the confluence of the Opaoa and Taylor Rivers (location shown in Figure 3). At this location, the river bank is surrounded by a relatively flat floodplain with stopbanks present $\sim 20 \mathrm{~m}$ inland. The land behind the stopbanks is at the same elevation as the top of the present day stopbanks and is relatively flat.

Ejecta material was confined to the floodplain, and lateral spread-induced cracks orientated sub-parallel to the river bank were evident. Cracks ranged in width from 1 to $30 \mathrm{~cm}$ and were associated with 1 to $5 \mathrm{~cm}$ of vertical settlement. Crack widths decreased with increasing distance from the apex of the inner meander bend and became discontinuous along the river bank further upstream. The total lateral spreading displacements in this area were typically less than $50 \mathrm{~cm}$. Fine-medium grey sand ejecta up to $10 \mathrm{~cm}$ thick and infilling the lateral spreading cracks were observed (Figure 9a). A hand auger performed adjacent to the river (on the floodplain) indicated that the soil profile at this site includes a silty sand cap about $2.2 \mathrm{~m}$ thick, underlain by fine-medium sand with trace silt. The water table was $1.5 \mathrm{~m}$ below the ground surface.

Cracking continued into the properties on Park Terrace that border the stopbank (Figure 9b). Permanent ground deformation, differential settlement of structures, separation between foundation slabs and the surrounding ground, and damage to the stopbanks were observed at these properties and a summary of the location of the cracks are shown in Figure 10. The total crack widths were $1-1.5 \mathrm{~m}: 0.3 \mathrm{~m}$ in floodplain and $0.7-1.2 \mathrm{~m}$ in the fill. Historic photographs indicate that the position of the stopbank in 1959 lay approximately $20 \mathrm{~m}$ north of Park Terrace. The affected properties shown in Figure 10 were constructed on an area of fill that raised the elevation of the zone between the historic stopbanks and present-day stopbanks, with the southerly extent of cracking just north of the position of the historic stop bank. 


\section{Damage to Stopbanks}

A network of stopbanks has been built in and around Blenheim to prevent flooding in the town and the plains. Present day stopbanks have been typically been built to an elevation 3-4 $\mathrm{m}$ above the surrounding river floodplain, and have a typical width (toe-toe) of $15-20 \mathrm{~m}$. The stopbanks have been built at various times during the development of Blenheim, with historic photos and records showing stopbanks in the 1930s, while most present-day stopbanks were built in the period between 1959 and 1980. The stopbank material has not been investigated in detail, but photographs of failed sections reveal well graded materials. It is likely that these stopbanks have been raised since their construction. Given their age it is most likely that the original stopbanks were unengineered structures.

Of the $180 \mathrm{~km}$ of stopbanks in the region, $\sim 2.5 \mathrm{~km}$ (cumulative) were damaged to varying degrees during the earthquake at locations (shown in Figure 2) associated with paleo channels or swamps. Damaged sections were built on geologically younger deposits compared to the surrounding undamaged sections. Horizontal and vertical displacements were found to vary significantly within the failure zone, and were accommodated through the development of systems of cracks, usually located on top of the stopbanks and running parallel to the stopbank. Accompanying phenomena, which were not observed in all cases, included the development of secondary systems of ground cracks and/or sand ejecta at the base of the stopbanks and orientated parallel to the riverbanks.

\section{Blind Creek}

At Blind Creek (indicated in Figure 2), the primary stopbank is set back from the river outside of a cut-off meander bend of the river associated with river avulsion and the construction of the Wairau Diversion in the 1960's (Figure 11). A secondary set of stopbanks runs parallel to the current channel of the Wairau River. A 200-m long section of the secondary stopbank was heavily damaged during the earthquake (Figure 12a), which corresponds with the location of the historical bed of the Wairau River. Cracks exhibited a maximum width and depth of $1 \mathrm{~m}$ and indicates that movement occurred to the north and south, away from the major axis of the stopbanks (Figure 11). Sand boils were observed on the foundation soils surrounding the stopbank closer to the river's edge as well as on the northern side of the stopbank within the paleo-channel marked on the figure. Slumping of the stopbank was also observed where Blind Creek flows underneath the stopbank through a culvert.

\section{Wairau Bar}

Lateral spreading and slumping were observed along a $100 \mathrm{~m}$ long section of the northern stopbank at the mouth of the Lower Wairau River (Wairau Bar; indicated in Figure 2). The damaged section corresponds to the position of the former river channel that existed prior to diversion and stopbank construction (Figure 2 and Figure 13). Cracks varied in width from 30 to $50 \mathrm{~cm}$ and exhibited vertical settlements of 20 to $120 \mathrm{~cm}$ (Figure 12b). No liquefaction ejecta was observed along the stopbank or in the mudflats exposed within the river channel. A series of lateral spreading cracks were observed along the inland edge of the stopbank within the paleo-channel and these were surrounded by fine grey sand ejecta.

\section{Wairau Diversion}

Lateral spreading-induced cracking was also observed along the northern and southern stopbanks of the Wairau Diversion and corresponds with the location of a paleo-stream channel recognizable by a depression in the landscape and by a change in vegetation (Figure 14). Lateral spreading on the northern stopbank was characterised by cracking ranging in width from approximately 30 to $50 \mathrm{~cm}$ and exhibiting 10 to $50 \mathrm{~cm}$ of vertical settlement (Figure 15). Localised cracking was observed at the base of stopbank proximal to the river. Lateral spreading along the southern stopbank resulted in cracking ranging in width from $\sim 2$ to $10 \mathrm{~cm}$ with $1-2 \mathrm{~cm}$ of vertical settlement. Lateral spreading was also observed along the river bank. No liquefaction ejecta was observed on either stopbank.

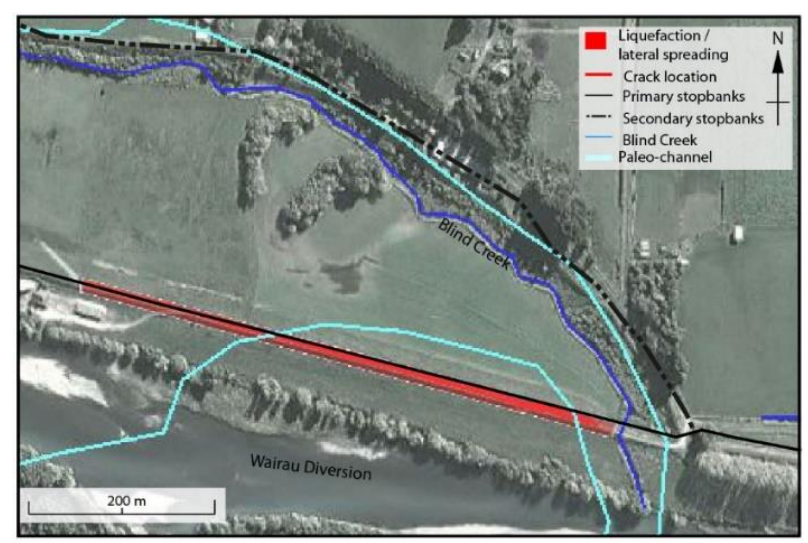

Figure 11: Overview of damage to the stopbank at Blind Creek. (Approx. coord. of centre of image: $\mathbf{- 4 1 . 4 4 2}$, $\left.173.978^{\circ}\right)$

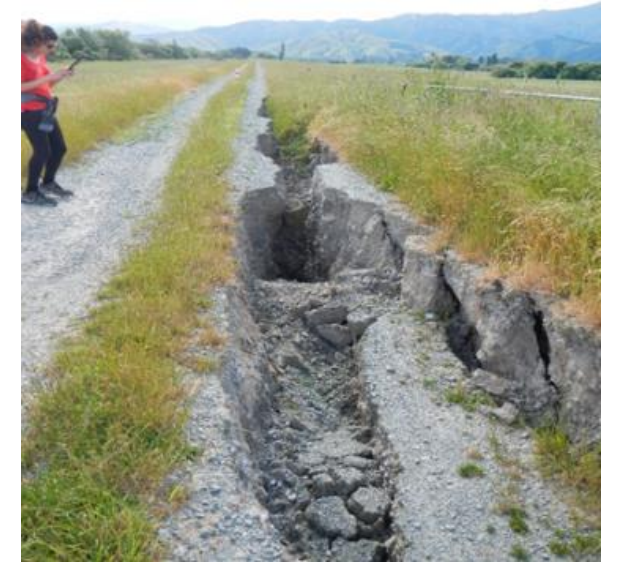

(a)

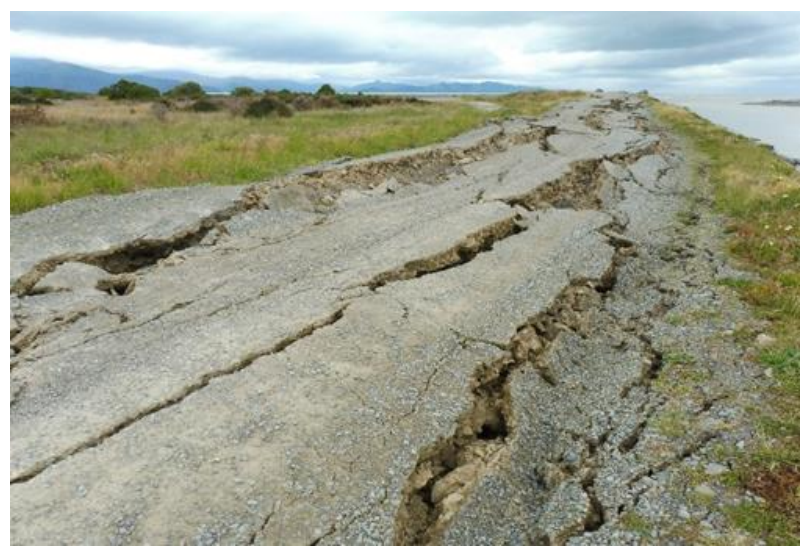

(b)

Figure 12: Examples of stopbank damage: (a) Blind Creek (-41.4407 ${ }^{\circ} 173.9791^{\circ}$, taken facing WNW); (b) Wairau Bar $\left(-41.5012^{\circ}, 174.0600^{\circ}\right.$, taken facing NE). 


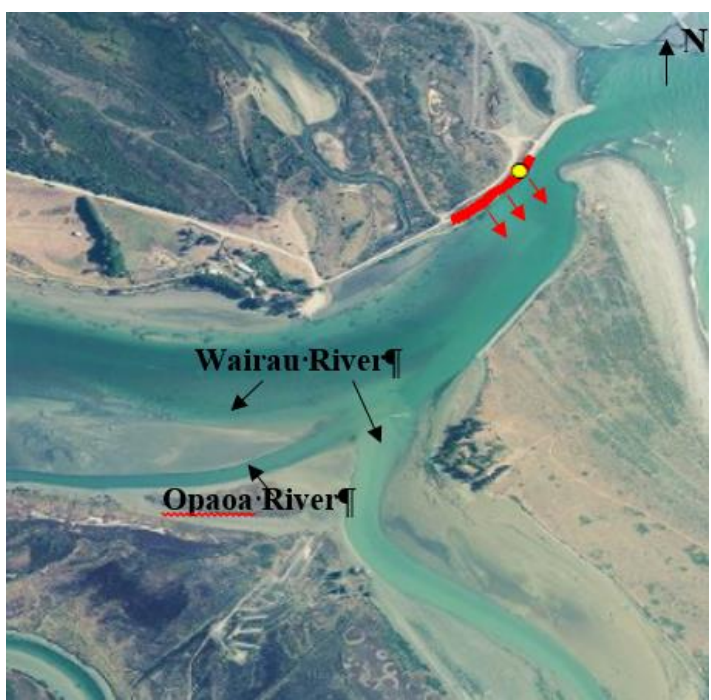

(a)

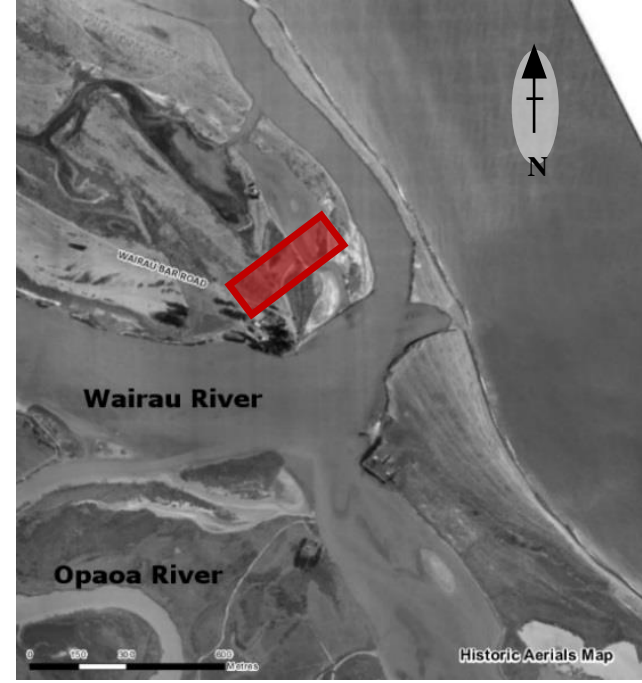

(b)

Figure 13: Aerial photographs showing location of damage stopbank at the mouth of the Wairau River: (a) Current landscape; (b) Landscape in 1948. (Approx. coord. of centre of images: $-41.504^{\circ}, 174.058^{\circ}$ ) Marlborough District Council (2017).

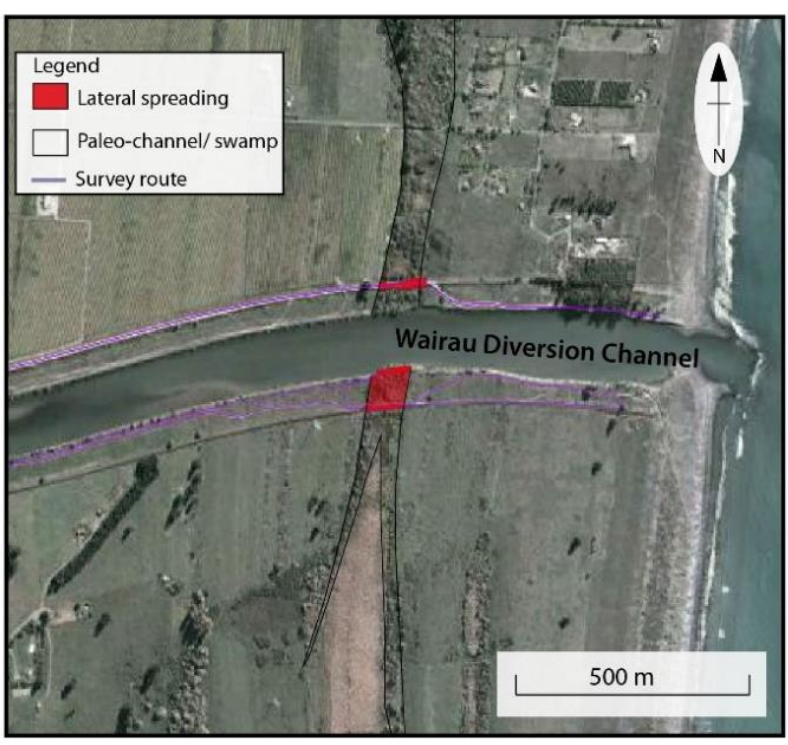

Figure 14: Overview of damage to the stopbank along the Wairau Diversion with the location of the paleo-channel and swamp indicated. (Approx. coord. of centre of image: $\left.-41.440^{\circ}, 174.022^{\circ}\right)$

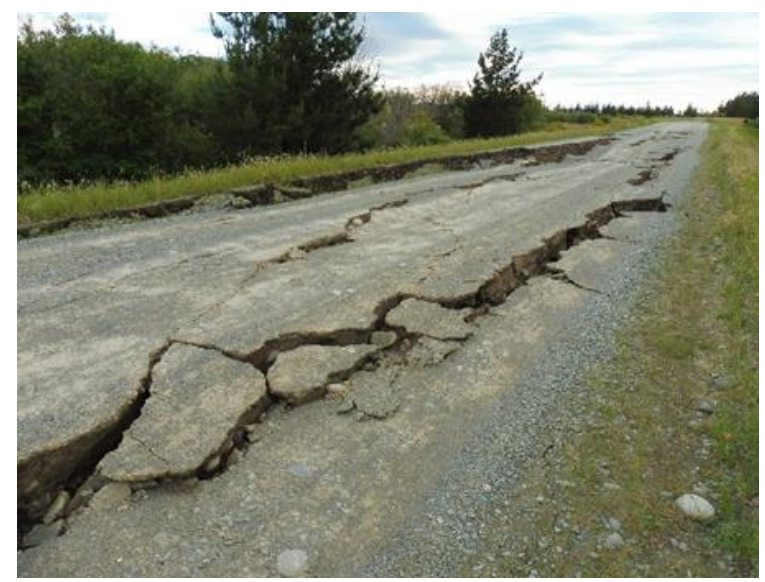

Figure 15: Lateral spreading induced cracking along top of northern stopbank $\left(-41.4387^{\circ}, 174.0214^{\circ}\right.$, taken facing E).

\section{Damage to River Banks}

Lateral spreading occurred proximal to the Wairau and Opaoa Rivers within the Wairau Plains (Figure 2). The majority of liquefaction and lateral spreading impacts were confined within the river floodplains (defined by the current stopbank network) and largely occurred on the inside of meander bends, or at locations with paleo features (both recent natural channels and man-made river diversions) readily identifiable in the historic aerial photos dating back to the 1930s. Most of the lateral spreading shown in Figure 2 has been mapped from aerial photography taken after the Kaikōura Earthquake. Cracks were typically within $75 \mathrm{~m}$ of the river channel, but at some locations (Figure 16 shows one example) were up to $300 \mathrm{~m}$ from the river. Measurements of lateral displacements at a few key sites indicate cumulative displacements between 1$5 \mathrm{~m}$ along these rivers. Cracks associated with the lateralspreading ranged in width from a few centimetres to over $1 \mathrm{~m}$ (Figure 16), generally reducing in width with distance from the river.

The Marlborough region has become an internationally recognised viticultural region, and an increasing amount of land close to the rivers has been converted to vineyards in recent times. The lateral spreading along the river banks caused significant damage to the farmland and vineyards present along the riverbanks (Figure 17). Many of these areas were cleared following the earthquake and new end-posts installed to allow the rest of the vines to continue to grow. A more detailed summary of the impacts to the vineyards and wineries is provided in Dizhur et al. [23].

\section{Marlborough Equestrian Park}

Severe ground distress was observed at the Marlborough Equestrian Park (shown in Figure 2), which is located at the former transition of the Wairau River from braided to meandering, and now comprises the start of the Wairau Diversion channel (Figure 2). The site is bounded by the Wairau Diversion to the north, the Wairau River to the west, and to the south and east by a stream that is a remnant of the initial meander bend of the Wairau River which was cut-off during the diversion of the river. The site is surrounded by stopbanks (Figure 2). The spatial location of cracks was mapped carefully within the boundaries of the Equestrian Park, but did not include the area immediately west of the park (covered in trees) which is adjacent to the Wairau River. 


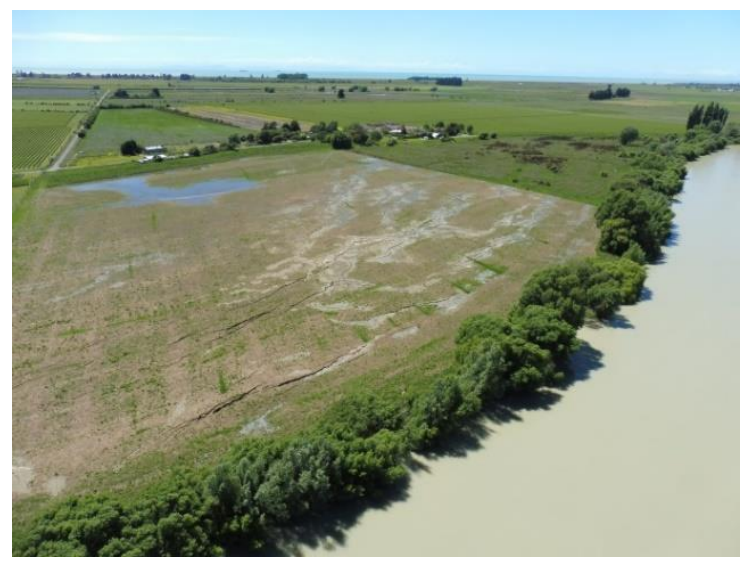

(a)

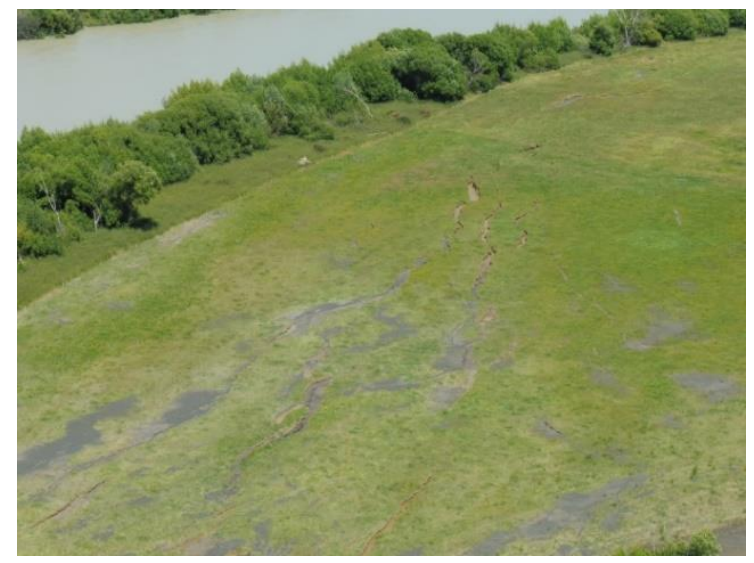

(b)

Figure 16: Lateral spreading and liquefaction ejecta on the eastern banks of the Lower Wairau River. (a) $-41.4687^{\circ}, 173.9807^{\circ}$, taken facing SE; (b) $-41.4854^{\circ}, 174.0160^{\circ}$, taken facing W. Photos: Marlborough District Council.

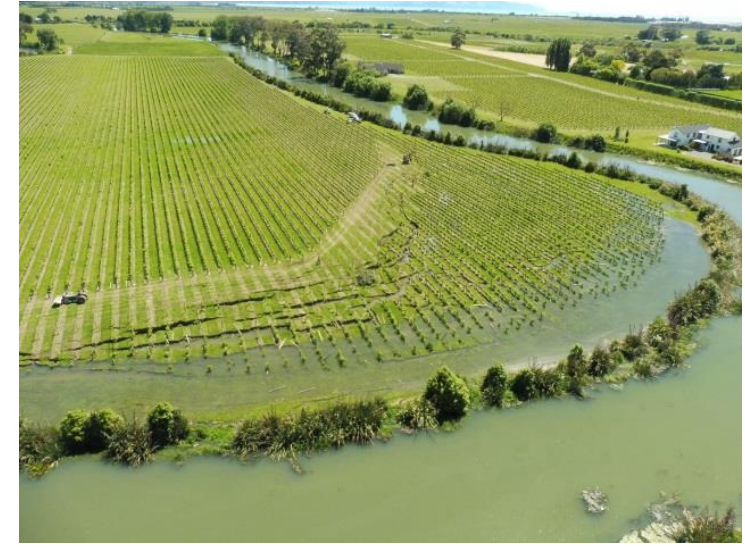

(a)

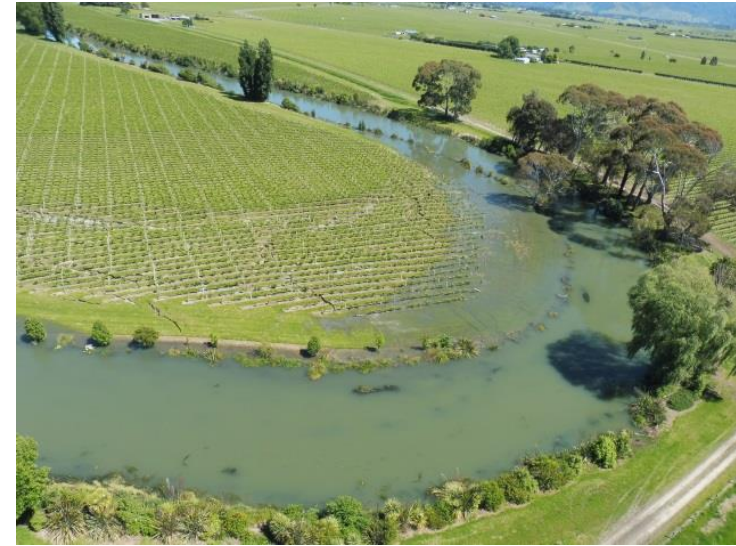

(b)

Figure 17: Examples of lateral spreading and sand ejecta damage to vineyards along the Lower Opaoa River. Photo taken 4 days after the earthquake showing completed vine repair and remnants of damaged vines. (a) $-41.5270^{\circ}, 174.0179^{\circ}$, taken facing $N E$; (b) $-41.5217^{\circ}, 174.0160^{\circ}$, taken facing NW. Photos: Marlborough District Council.

Lateral spreading was accompanied by widespread ejecta across the site (Figure 18) with the volume of ejecta most severe in the southern part of the park where the ground elevation was the lowest (Figure 19). It should be noted that the observations in Figure 18 are only considered complete in the grassy area of the park. As shown, lateral spreading is aligned with the position of the Wairau River at the time when the property boundaries were being drawn. Lateral spreading cracks ranged in width from $\sim 10-70 \mathrm{~cm}$ and exhibited vertical displacements up to $70 \mathrm{~cm}$. Total lateral movements towards this old river channel was of the order of $1-2 \mathrm{~m}$. Soil profiles derived from hand augers in this area of cracking showed silty sand to a depth of approximately $1.5 \mathrm{~m}$ below which was clean sand that changed from brown to a bluish-grey colour at around $2.8 \mathrm{~m}$ depth.

Liquefaction ejecta was present across much of the Equestrian Park. Historic photos [20] indicate that the position of the Wairau River moved significantly in the past 100 years. Accordingly, buried river channels are likely present across the park which explains the widespread ejecta at this site. Particle size distribution characteristics of ejecta samples are summarised in Figure 20. Specifically, the PSD of the ejecta silt layer that capped the underlying fine-medium sand ejecta are shown in this figure. The segregation of the particles of different sizes occurs during the fluidization and deposition of the liquefied soil.

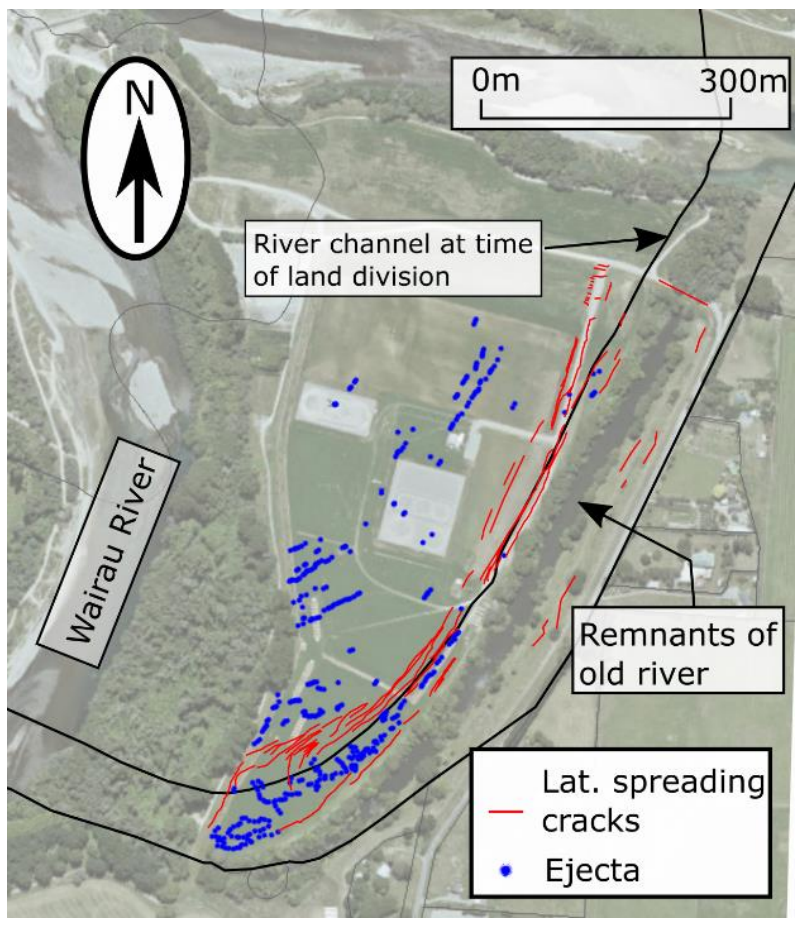

Figure 18: Lateral spreading and ejecta at Marlborough Equestrian Park (Approx. coord. of centre of image: $\left.-41.445^{\circ}, 173.976^{\circ}\right)$ 


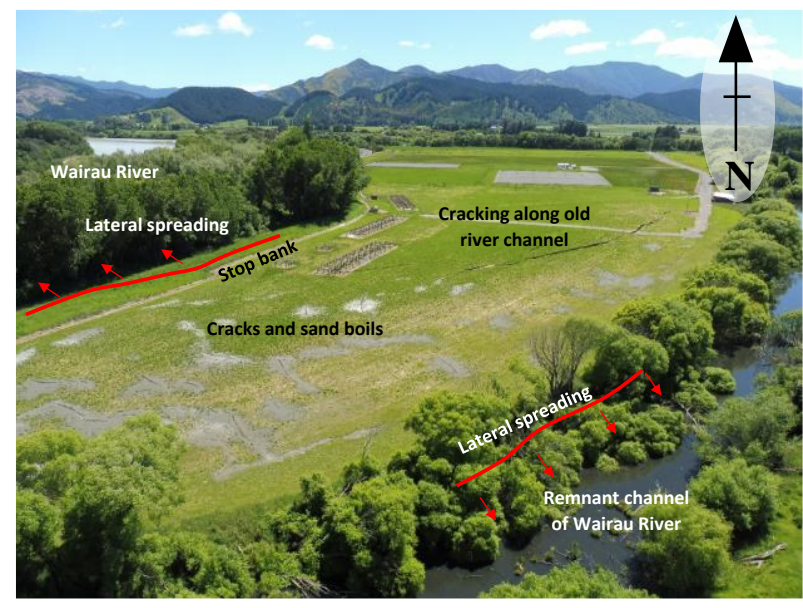

Figure 19: Aerial view of Marlborough Equestrian Park and summary of liquefaction induced damage (-41.4474, 173.9768 ${ }^{\circ}$, facing NE). Photo: Marlborough District Council).

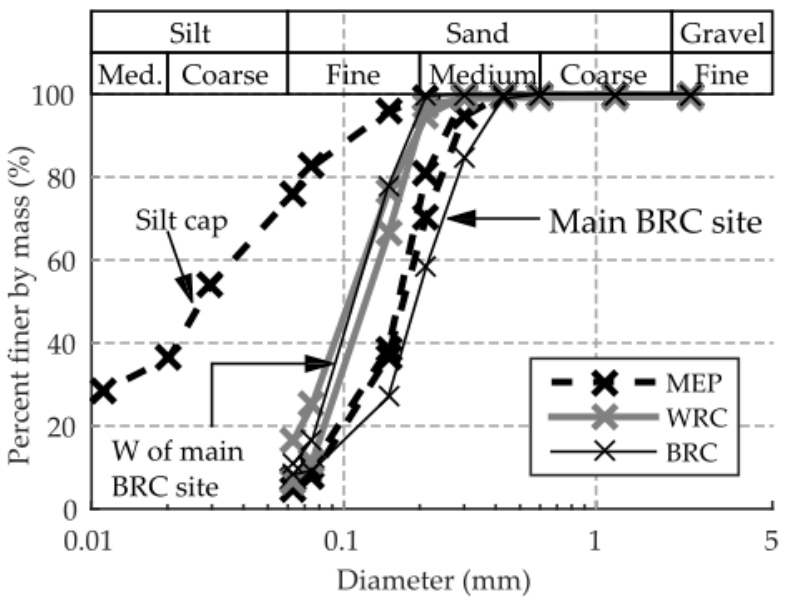

Figure 20: Particle size distributions of ejecta samples from along the Wairau River (MEP=Equestrian Club,

$B R C=$ Blenheim Rowing Club, WRC=Wairau Rowing Club).
Blenheim Rowing Club

Severe lateral spreading was observed at the Blenheim Rowing Club on the southern bank of the Wairau River, with lateral spreading displacements (estimated from cumulative crack widths) between 2-5 m. Lateral spreading cracks ranging from $0.5-1.5 \mathrm{~m}$ in width were observed within $75 \mathrm{~m}$ of the river at the site (Figure 21 and Figure 22). Many of these cracks also had a number of associated ejecta features that were 1-2 $\mathrm{m}$ in diameter. Only minor evidence of liquefaction was observed around the perimeter of the Blenheim Rowing Club building. Two hand augers in the region of severe lateral spreading indicated that the soil profile consisted of silty sand, transitioning to clean fine sand between $1.5-2.5 \mathrm{~m}$ below the ground surface. The clean sand changed colour from brown to bluish-grey between 2.5-4 $\mathrm{m}$ depth.

Historic maps and property boundaries show that the river formerly flowed through an S-bend (Cook, 1895) with much of the damage appearing to be confined to the boundaries of the paleo-channel. Particle size distribution characteristics of ejecta samples are summarised in Figure 20. At the main rowing club site, the ejecta was composed of grey mediumfine sands. West of the main site (at the left side of Figure 21), the ejected material was fine sand.

\section{Wairau Rowing Club}

Severe lateral spreading was observed close to the river at the Wairau Rowing Club, located adjacent to the southern bank of the Wairau River (Figure 2). A key feature of this site (Figure 23 ) is the Grovetown Lagoon, an ox-bow lake cut off from the main channel during a flood in 1861. Drainage channels have been cut through the north and south paleo channels. The grassy area visible to the east and west of the club house in Figure 23 marks the position of the old river channel. A stopbank runs approximately N-S through the site, and the 3level clubhouse was built so that it extends into the west side of the stopbank and has its second floor level with the crest of the stopbank. East of the clubhouse, the land (above the paleo channel) gently slopes down to the river.

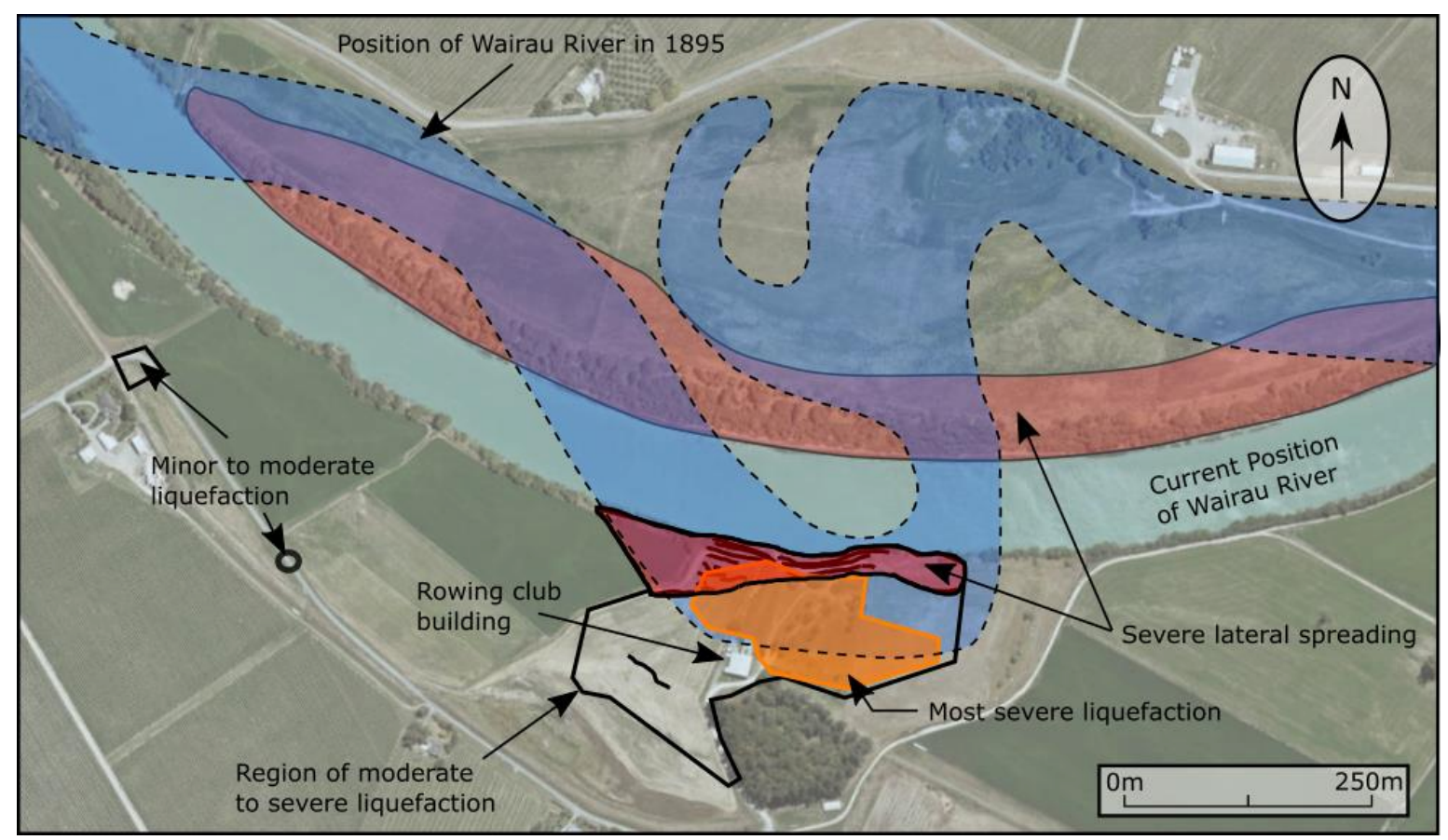

Figure 21: Summary of observations at Blenheim Rowing Club (Approx. coord. of centre of image: $-41.489^{\circ}, 174.007^{\circ}$ ). Basemap: Marlborough District Council [20]. 


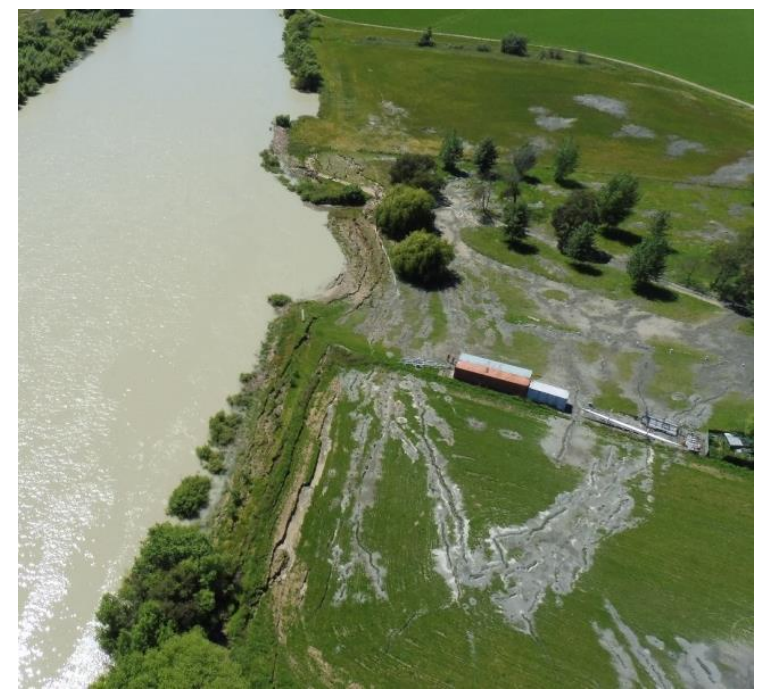

Figure 22: Aerial view of liquefaction manifestation at the Blenheim Rowing Club (Approx. coord: -41.4882 ${ }^{\circ}$, $174.0100^{\circ}$, taken facing E). Photo: Marlborough District Council.

The lateral spreading cracks were observed within $20 \mathrm{~m}$ of the Wairau River banks in the area extending between the paleochannels linking the Wairau River and the Oxbow lake.
Cracks ranged in width from 1-2 m (also representative of the cumulative lateral displacements at this site), and were associated with up to $50 \mathrm{~cm}$ of vertical settlement (Figure 24). A significant volume of ejecta vented into the drainage channels, but this was removed soon after the earthquake to restore the channel. A line of sand boils orientated parallel to the river was additionally observed $\sim 70 \mathrm{~m}$ inland from the river in the grassy area between the drainage channels. The sand boils transitioned into an $\sim 10 \mathrm{~cm}$ wide lateral spreading crack within the surrounding vegetation. Numerous minor to moderate sand boils were also observed around the rowing club building on the west side of the stopbank. Lateral spreading cracks also formed along the southern drainage channel (i.e. within the paleo channel) proximal to the rowing club house (Figure 23). Particle size distribution characteristics of ejecta samples (collected from both sides of the stopbank) are summarised in Figure 20, and were comprised of finer sand than samples from both the Blenheim Rowing Club and the Equestrian Club sites.

Around the clubhouse building, there appeared to be only minor ground distress, with $20 \mathrm{~cm}$ of stopbank settlement (evident from old soil lines on the building), and some ground cracking on the western side of the building (i.e. towards the lagoon). The clubhouse had only minor signs of damage, which included the concrete slab on the embankment (in front of the building) separating from the clubhouse, leaving a gap of approximately $10 \mathrm{~cm}$ as shown in Figure 25 .

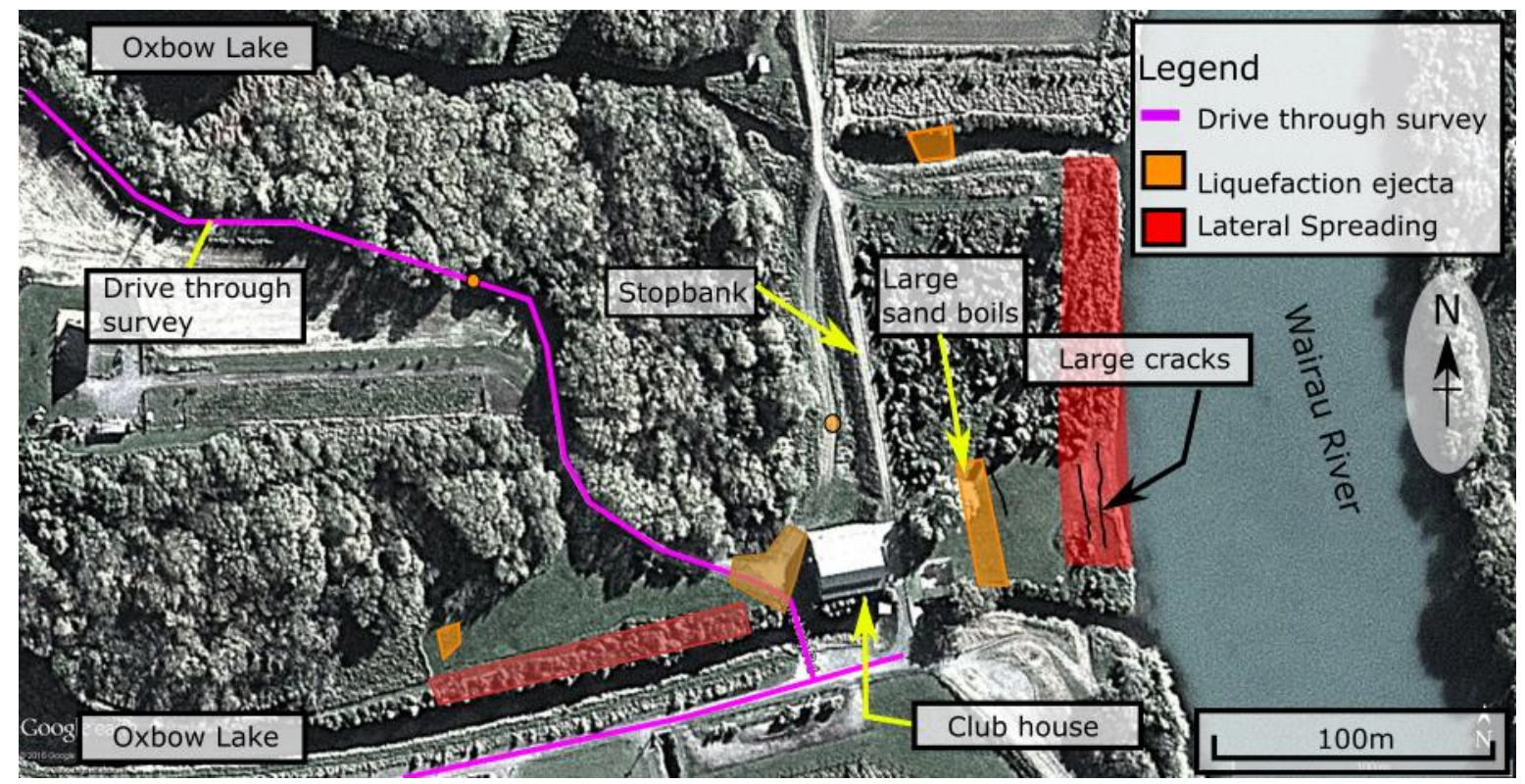

Figure 23: Summary of observations at Wairau Rowing Club (Approx. coord. of centre of image: $-41.476^{\circ}, 173.984^{\circ}$ ).

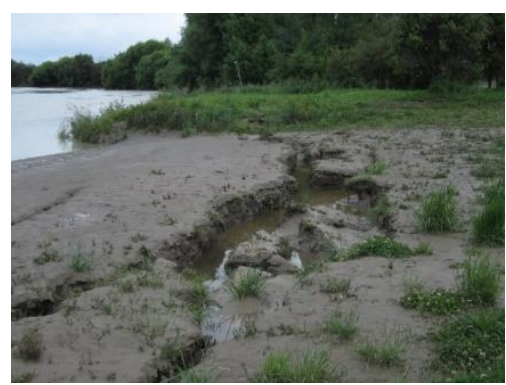

(a)

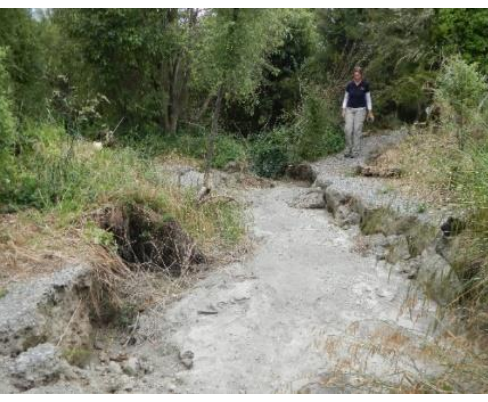

(b)
Figure 24: Lateral spreading cracks adjacent to the Wairau River at the Wairau Rowing club (a) $-41.4765^{\circ}, 173.9862^{\circ}$, taken facing $S$; (b) $-41.4761^{\circ}$, $173.9860^{\circ}$, taken facing $S$.

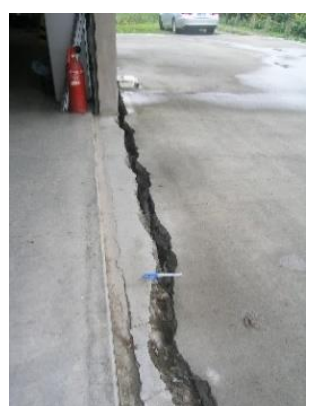

Figure 25: Separation of concrete slab from clubhouse $\left(-41.4768^{\circ}, 173.9855^{\circ}\right.$, taken facing $N$ ). 


\section{Damage South of Blenheim}

A drive-through survey was conducted along State Highway 1 (SH1) south of Blenheim. Typical damage (excluding the major impacts of fault rupture and landslides described in Dellow et al. 2017) included cracking along the roadside as well as settlements of up to $\sim 30 \mathrm{~cm}$ in the bridge approaches. Detailed inspections were not generally carried out in this area except near the location of the strong ground motion station at the Ward Fire station (WDFS).

Some liquefaction-induced lateral spreading caused minor damage at the 4-span Needles Creek Bridge, located just north of the town of Ward about $35 \mathrm{~km}$ south of Blenheim on SH1. Figure 26 shows some of the damage observations at the Needles Creek Bridge. Moderate liquefaction ejecta was observed under the bridge between several of the piers, and minor ejecta was found in one location on the north bank, $25 \mathrm{~m}$ west of the bridge. Between the bridge piers, the ejecta had separated into a sandy portion near the piers (i.e. where it exited from the ground) and clayey silt which had pooled on the raised floodplain of the creek. The free-field ejecta $(25 \mathrm{~m}$ west of the bridge) was very coarse compared with the ejecta beneath the bridge and elsewhere in the region. Free-field lateral spreading $30 \mathrm{~m}$ west of the bridge (Figure 26 a) resulted in localised movements of up to $50 \mathrm{~cm}$, with individual cracks being $15-25 \mathrm{~cm}$ wide. A local farmer reported that there was additional lateral spreading located east of the bridge, but this was several hundred meters away and not investigated.

The lateral spreading resulted in some structural damage to several of the bridge piers and in the tops of some visible abutment piles. As shown in Figure $26 \mathrm{~b}$-c, the inward movement of the soil has caused some rotation of the piers. The movement caused single cracks to develop at the top and bottom of the piers, particularly at the north end of the bridge shown in Figure 26 b-c. Pipes that were attached to the east side of the bridge to carry services failed at joints between sections of pipes.

Settlements of $\sim 15 \mathrm{~cm}$ were observed at both abutment walls, exposing the underside of the abutments as shown in Figure $26 \mathrm{~d}$-e. Horizontal cracks between 1-5 mm wide were present at the top of the visible piles supporting the abutment. Relative soil-pile displacements of $25-30 \mathrm{~cm}$ were evident from the gaps on the downward side of abutment piles. Gaps of $10-25 \mathrm{~cm}$ were visible around the three bridge piers, with small lateral spreading cracks also visible (Figure $26 \mathrm{f}$ ). All of the damage modes at the Needles Creek Bridge were similar to the typical short-span bridge damage observed in Christchurch following the 2010-2011 Canterbury earthquakes [24].

\section{KAIKŌURA}

The township of Kaikōura is located on the east coast of the South Island, New Zealand, and $100 \mathrm{~km}$ SSE of Blenheim. The urban population is approximately 2000 , with an additional 2000 people living in the nearby rural areas at the time of the 2013 census [11]. The urban area of Kaikoura covers an area of $\sim 7 \mathrm{~km}^{2}$ and is predominantly concentrated in a thin band extending $500 \mathrm{~m}$ inland from the coast. The township is positioned at the eastern-most extent of the transpressive strike-slip Hope Fault which results in the uplift northeast-trending Seaward Kaikōura range located to the west of the township. The Kaikoura Peninsula is located to the southeast of the town centre and comprises uplifted flights of marine terraces underlain by of Late Cretaceous-Paleogene limestone and siltstones as well as upper Tertiary siltstones, and reflects continued uplift of the region throughout the Quaternary [25].

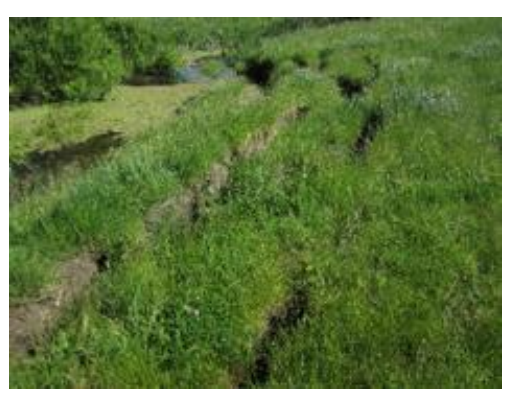

(a)

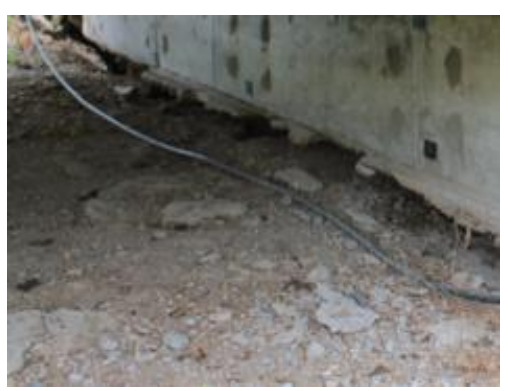

(d)

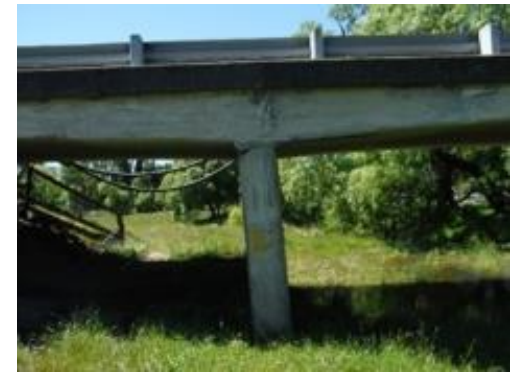

(b)

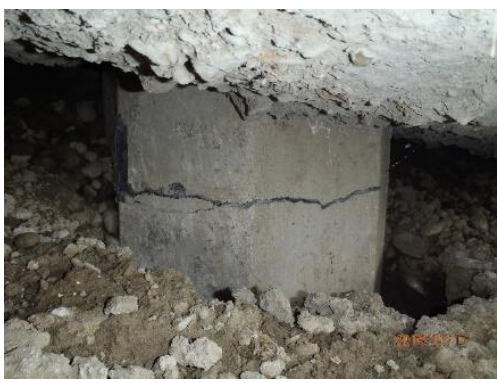

(e)

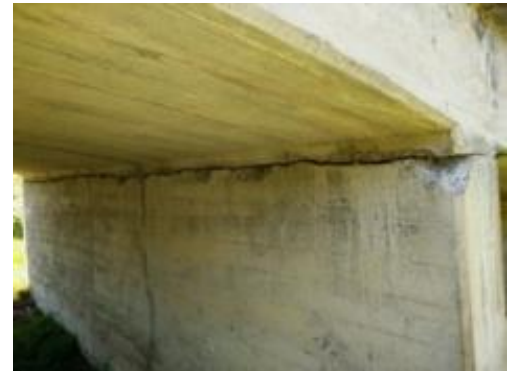

(c)

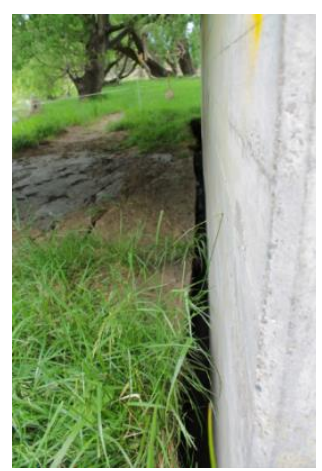

(f)

Figure 26: Damage at Needles Creek Bridge $\left(-41.8217^{\circ}, 174.137^{\circ}\right)$ : (a) Tilting of first pier from north abutment looking east; (b) Cracking across the top of first pier from north abutment caused by tilting, taken facing SE; (c) Subsidence of fill exposing base of north abutment, taken facing $N W$; (d) Free-field lateral spreading cracks, taken facing $W$. 


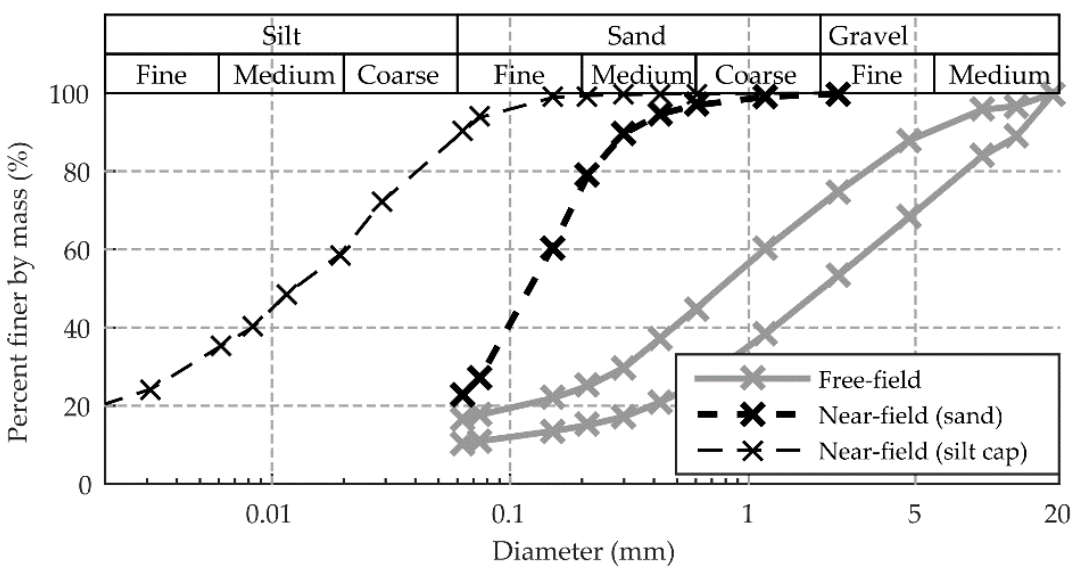

Figure 27: Particle size distributions of ejecta at Needles Creek Bridge.

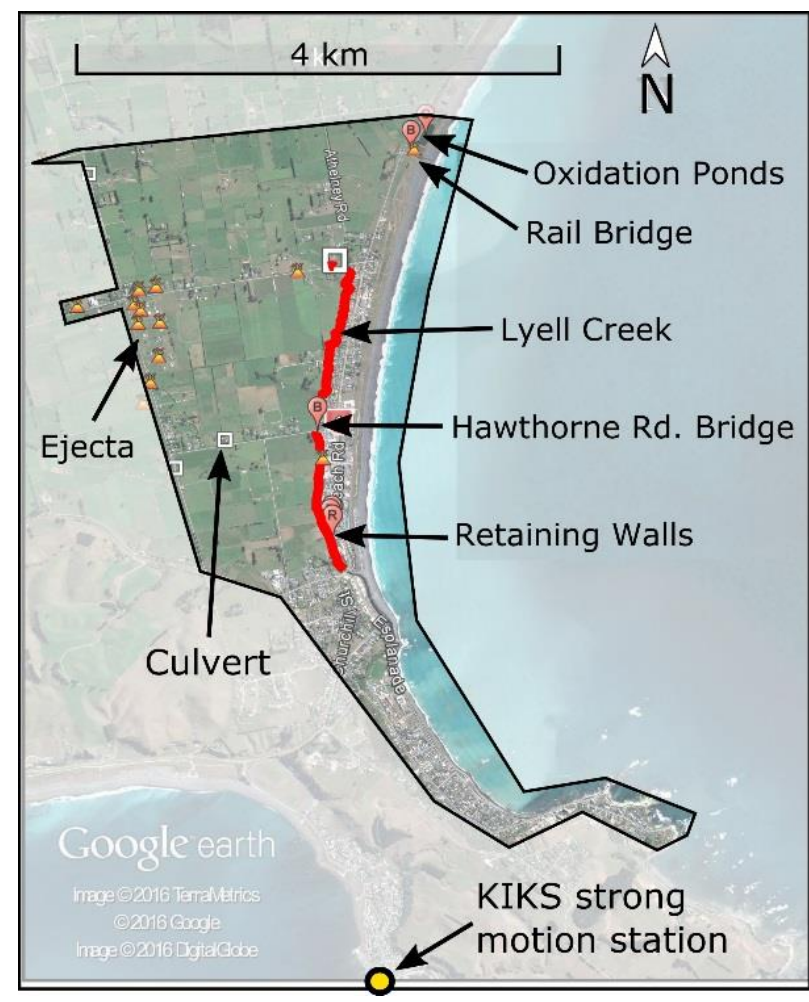

Figure 28: Reconnaissance in Kaikōura (Approx. coord. of image: $-42.389^{\circ}, 173.682^{\circ}$; Basemap: Google).

The town centre is built close to the coast upon uplifted beach deposits and alluvial out-wash fans of the braided Kowhai and Hapuku Rivers which flow eastward from the Seaward Kaikōura Range. The region is predominantly underlain by alluvial gravels with interspersed sands deposited by the braided rivers which regularly avulsed across the region. The alluvial sediments are cross-cut by channels and associated flood deposits of smaller streams which transect the fan surfaces. The alluvial sediments within $\sim 500 \mathrm{~m}$ of the coast are inter-fingered with coastal gravels and sands; the maximum inland extent is likely reflected by Lyell Creek which runs along the western most extent of the highly developed region of the township.

There is one strong motion station in the Kaikōura area, located on the rocky Kaikoura Peninsula to the south of town (Site Class B according to NZS1170.5 [14]). During the main earthquake event, PGAs of $0.22 \mathrm{~g}$ (horizontal geometric mean) and $0.27 \mathrm{~g}$ (vertical) were recorded. Several aftershocks occurred within 24 hours, including 3 events with $\mathrm{M}_{\mathrm{w}}$ greater than 6 with a nominal "epicenter" within $35 \mathrm{~km}$ of Kaikōura. However, accelerations during the main shock were significantly larger than the aftershock events which had horizontal PGAs less than $0.1 \mathrm{~g}$. It is assumed that the damage sustained in Kaikoura arose as a result of the main earthquake, though significant excess pore pressures may have remained at the time of the aftershocks.

Major landslides during the Kaikōura earthquake severely affected the land-access to the town of Kaikōura, damaging and blocking all three roads into the town as well as causing extreme damage to the railway lines. Scientific reconnaissance teams did not reach the township until the $8^{\text {th }}$ December 2016. Prior to this, practicing engineers were able to reach the region and began compiling observations of damage in the town. In this section the observations of the reconnaissance team that visited the town between the $8^{\text {th }}$ and $10^{\text {th }}$ December 2016 are described, as are the wider set of damage observations that were available.

The area covered by the overall reconnaissance efforts is shown in Figure 28, along with key locations where damage was observed. Due to the rural nature of this area, the damage to infrastructure was quite low. Damage was concentrated along Lyell Creek, where large lateral displacements were observed within $30 \mathrm{~m}$ of the creek resulting in heavy damage to many houses built close to the river, and to one short-span bridge. While these displacements resulted in cumulative crack widths of up to $3 \mathrm{~m}$, it was apparent that the driving mechanism was not due to classic liquefaction-induced lateral spreading, as discussed subsequently. Other damage in the region included cracking and deformation of the roads, as well as some damage to the liner systems in embankments at the oxidation ponds to the north of the town. Liquefaction ejecta was noted in some areas outside of the main township, though the overall impact of liquefaction was quite small.

\section{Lateral Movements along Lyell Creek}

Large lateral ground displacements were observed along both sides of Lyell Creek (shown in red in Figure 28) and were highly variable from location to location. On the east side of the creek (boundary of the township), horizontal displacements of up to $\sim 3 \mathrm{~m}$ were recorded at a few locations in the area between 140 and 190 Beach Road ( 500 m stretch of road), though cumulative crack widths of 1-2 m were quite common. The area of major ground cracking was generally concentrated within $30 \mathrm{~m}$ of Lyell Creek. The land on the west side of the creek is mostly used for agricultural purposes and hence ground displacements had little direct impact on built structures.

The ground movements caused significant damage to residential properties next to the creek, and included separation of concrete floor slabs (and consequent structural distress), differential settlements, uplift of manholes, and large 
lateral displacement of light structures. Examples of damage to houses along Lyell Creek are shown in Figure 29 through Figure 33.

At the property shown in Figure 29, the garage (centreline located $\sim 10 \mathrm{~m}$ from the creek) displaced $\sim 1 \mathrm{~m}$ directly west towards the creek. The movement was accompanied by a vertical drop relative to the concrete slab originally leading to the garage. At the north end of the garage structure, some ejected soil was reported. The ground cracks at this location extended up to $30 \mathrm{~m}$ from the river. A similar example is shown in Figure 30, where the lateral movement towards the creek and the vertical offset are both of the order of $1 \mathrm{~m}$. It should be noted that at this location, the apparent ground movement between the photographer and the garage is much larger than the displacement of the garage building. The house shown in Figure 31 was built on short timber posts which were fixed into small concrete footings. Large lateral ground movements occurred at this site towards the creek. As shown, this resulted in the foundations at the west end of the house being pulled laterally by the horizontal movement, but also being left exposed by the vertical movements.

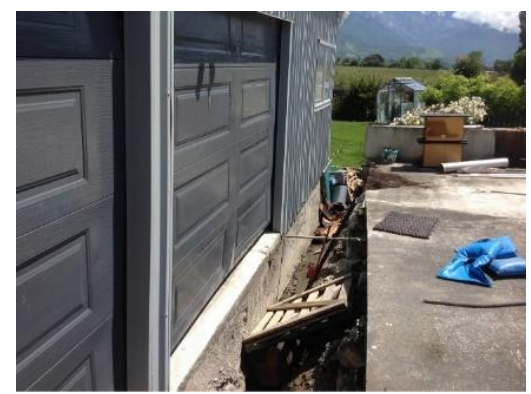

(a)

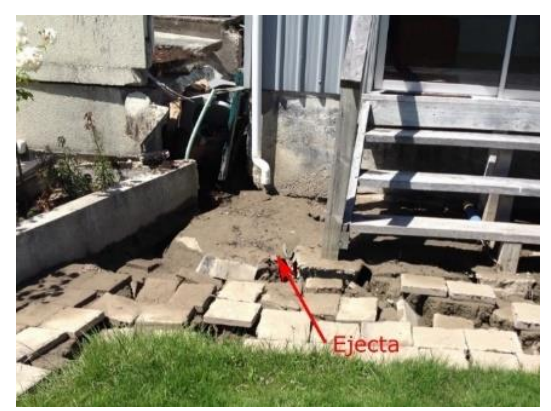

(b)

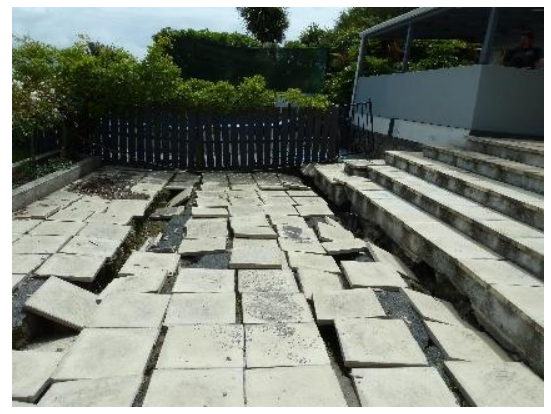

(c)

Figure 29: Large displacement at a property adjacent to Lyell Creek (approx. coordinates: $\left.-42.382^{\circ}, 173.680^{\circ}\right):($ a) Separation of concrete slabs and garage $(70 \mathrm{~cm}$ wide) due to lateral movements. (taken facing $N$ ); Note the garage has moved laterally in the picture (i.e. Lyell Creek is behind the garage, to the left of the picture). (b) vertical gap in wall due to lateral movement and ejecta. (taken facing $S$ ). (c) Cracking in the ground at $30 \mathrm{~m}$ from the river.

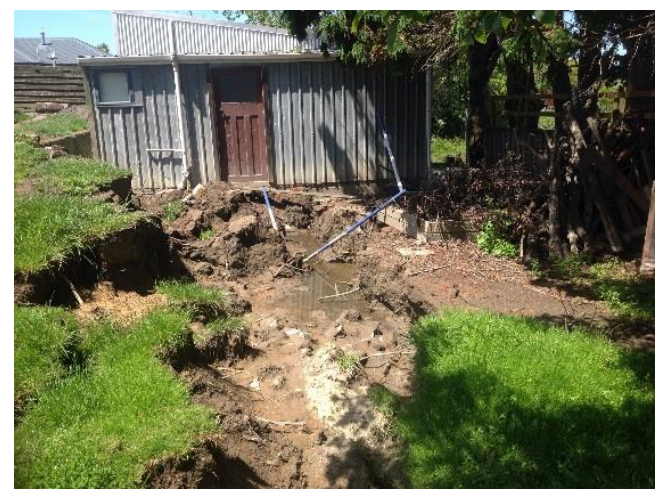

Figure 30: A garage/shed at a house on Beach Road displaced $\sim 1 \mathrm{~m}$ towards Lyell Creek, and moved downwards $\sim 1 \mathrm{~m}\left(-42.3860^{\circ}, 173.6783^{\circ}\right.$, taken facing $\left.S\right)$.

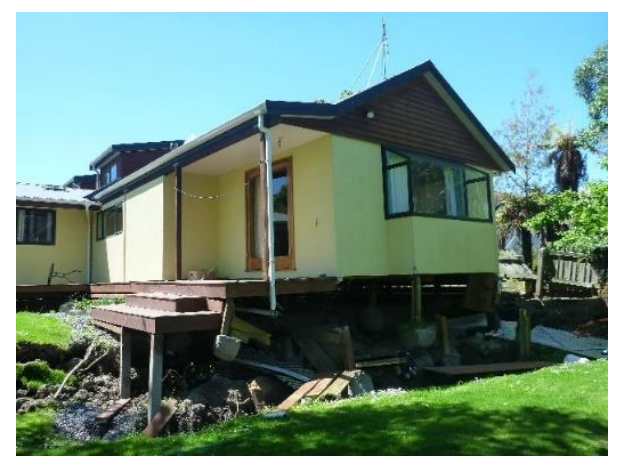

(a)

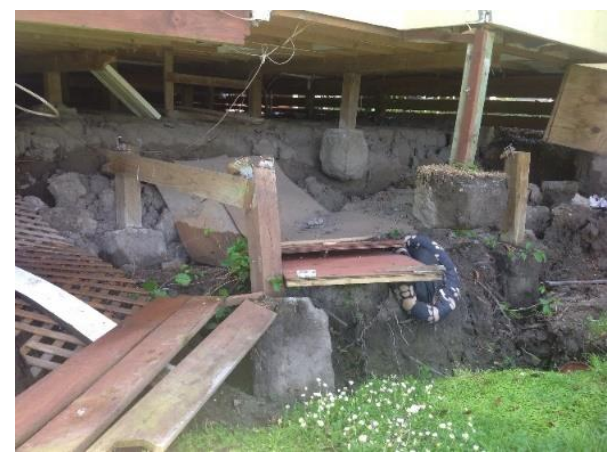

(b)

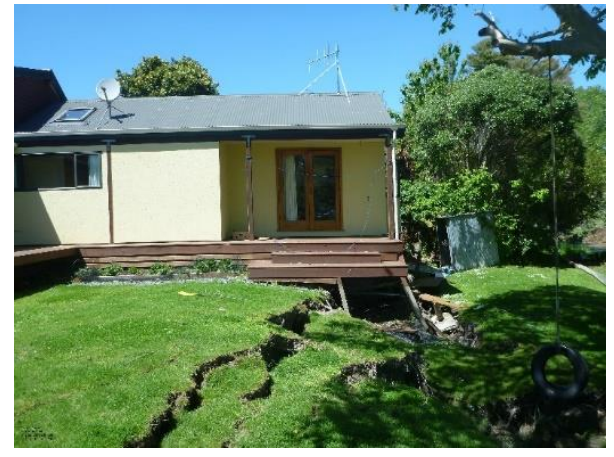

(c)

Figure 31: Complete loss of support to foundations at $W$ end of house on Beach Road $\left(-42.3851^{\circ}, 173.6783^{\circ}\right)$. (a) taken facing NE, (b) taken facing $S E$, (c) taken facing $S$. 


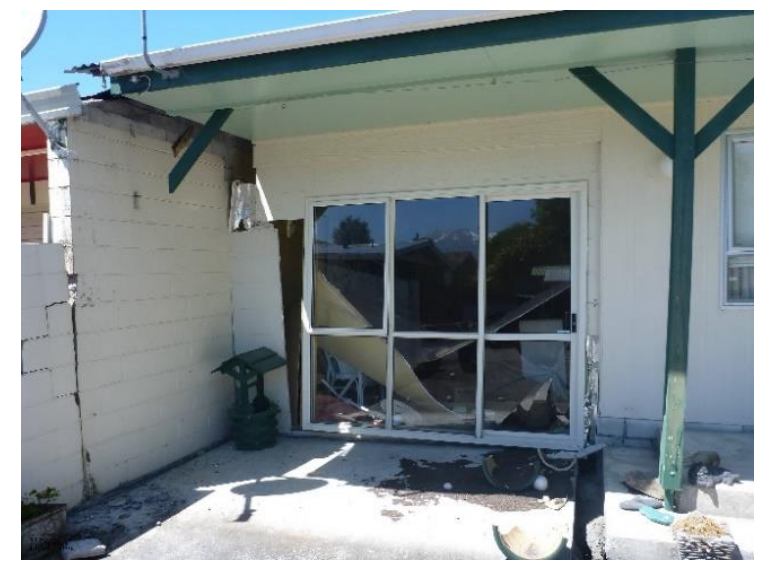

(a)

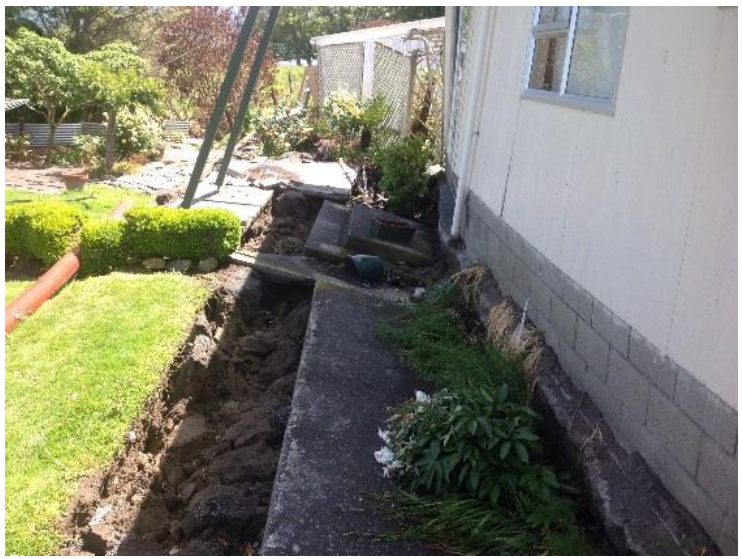

(b)

Figure 32: (a) Vertical gaps developed in a semi-detached house (taken facing S). Note: cracks are roughly parallel to Lyell creek (b) Gapping on the W side of the house (taken facing $E$ ). Note rotation of walls and posts caused by the differential slab movements $\left(-42.3857^{\circ}, 173.6784^{\circ}\right)$.

The large lateral ground movements caused horizontal gaps to develop within some houses, an example of which is shown in Figure 32. This house was semi-detached, with the partition (visible in the left of Figure 32a) between the two houses located around $28 \mathrm{~m}$ from the creek. Horizontal gaps are visible in the photo (Figure 32a) at both sides of the door portal. At the west end of the house, the large cumulative ground movements caused some bending of the end wall of the house, as well as rotation of the two green posts visible in the top left of Figure $32 \mathrm{~b}$, both as a result of the roof constraining lateral movements at the top of the structure.

A number of tanks located near Lyell Creek, as well as septic tanks in rural Kaikōura, experienced uplift relative to the ground. Figure 33 shows one such tanks located close to the Lyell Creek. This tank was located close to the house shown in Figure 31, and it should be noted that there were no reports of liquefaction ejecta in the immediate area.

Common features in areas with large horizontal ground movements (typically on the order of $0.5-2 \mathrm{~m}$ ) was that the zone of movement was located within $10-20 \mathrm{~m}$ of the river channel, was often associated with large vertical offsets, as shown in Figure 31 and Figure 34. These observations suggest that the free face of the creek was an important contributor to these localised displacements. There was a general lack of liquefaction ejecta both in these zones of displacement and in the surrounding areas. Cone penetration test (CPT) investigations indicate that soft, non-liquefiable deposits are present in the upper portions of the soil profile adjacent to the creek. In some locations, such as the example which will be discussed, these soft deposits extend deeper than $10 \mathrm{~m}$, while in other areas, very stiff sands underlay a few metres of these soft soils. Hence, it is likely that the soft materials near the surface are responsible for the large ground movements around Lyell Creek.

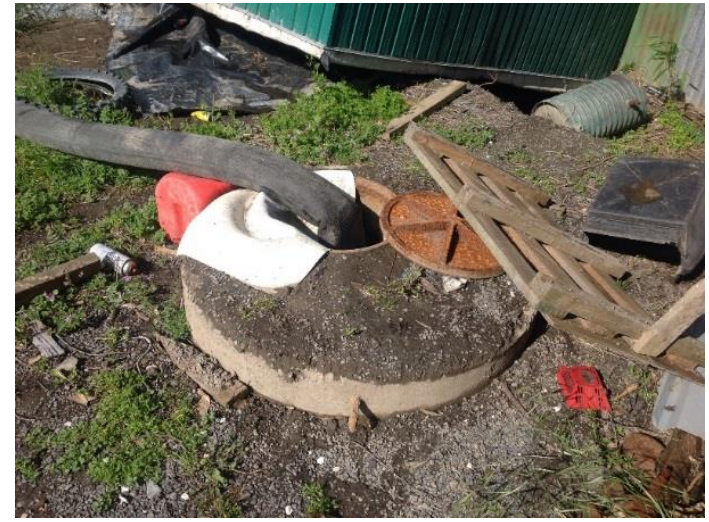

Figure 33: Floatation of manhole on Beach Road near to Lyell Creek $\left(-42.3848^{\circ}, 173.6783^{\circ}\right.$ taken facing $\left.S W\right)$.

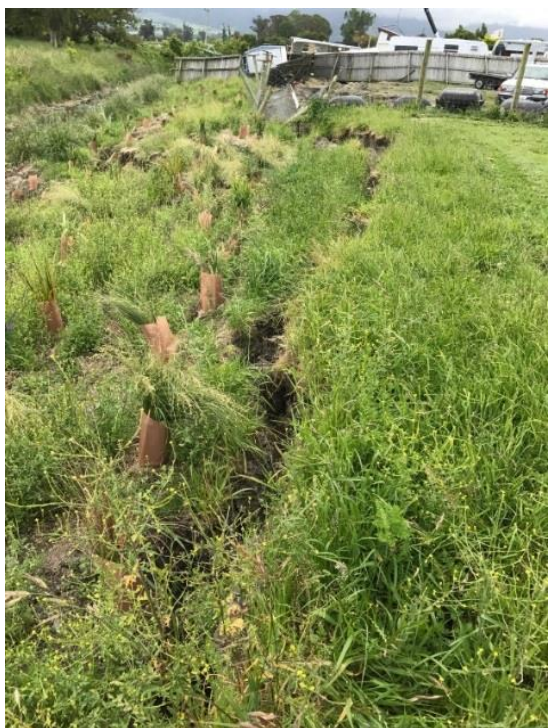

Figure 34: Lateral ground movements associated with vertical settlements in grassy area between Beach road and Lyell Creek. Note: Cracks are associated with vertical offsets and blocks have rotated away from the creek $\left(-42.3902^{\circ}\right.$, $173.6777^{\circ}$, taken facing $\mathrm{N}$ ).

In the area $\sim 100 \mathrm{~m}$ south of the Hawthorne Road bridge crossing Lyell Creek (Figure 35), a small number of CPT were performed after the earthquake. The $\log$ from the CPT sounding performed $\sim 15 \mathrm{~m}$ east of the creek is shown in Figure 36 and indicates that most of the soil profile in this location is very soft clay-like material $\left(\mathrm{I}_{\mathrm{c}} \approx 2.8-3.1\right.$ between $1-4 \mathrm{~m}$ depth and $\mathrm{I}_{\mathrm{c}} \approx 3.2$ between $5-11 \mathrm{~m}$ depth). There is a notable sandy layer at a depth of $\sim 4 \mathrm{~m}$. However, the normalised tip resistance $\left(\mathrm{q}_{\mathrm{c} 1 \mathrm{~N}}\right)$ values are in excess of 200 atm, indicating dense soil which is unlikely to have liquefied or developed significant shear strain during the ground shaking (though post-earthquake softening in this layer due to void redistribution is possible).

The magnitudes of permanent lateral ground displacements were estimated by summing up measured ground fissures along three lines (transects: KK_T1, KK_T2, and KK_T3, Figure 35) on the east side of Lyell Creek. The transects were carried out between the river channel and the last clearly 
identifiable crack along the heading being traversed. The transects were oriented perpendicular to Lyell Creek and parallel to the direction of ground movement, with KK_T1 being close to where CPT 88546 was performed and the site shown in Figure 34. The other two transects were located $\sim 150 \mathrm{~m}$ (KK_T2) and $300 \mathrm{~m}$ (KK_T3) to the south. Consistent with observations elsewhere along the creek, the cracks at the transect locations extended between $10-20 \mathrm{~m}$ from the river. Cumulative measured horizontal ground crack widths were in the range of $0.6-1.2 \mathrm{~m}$, while cumulative vertical displacements were between $0.4-0.8 \mathrm{~m}$.

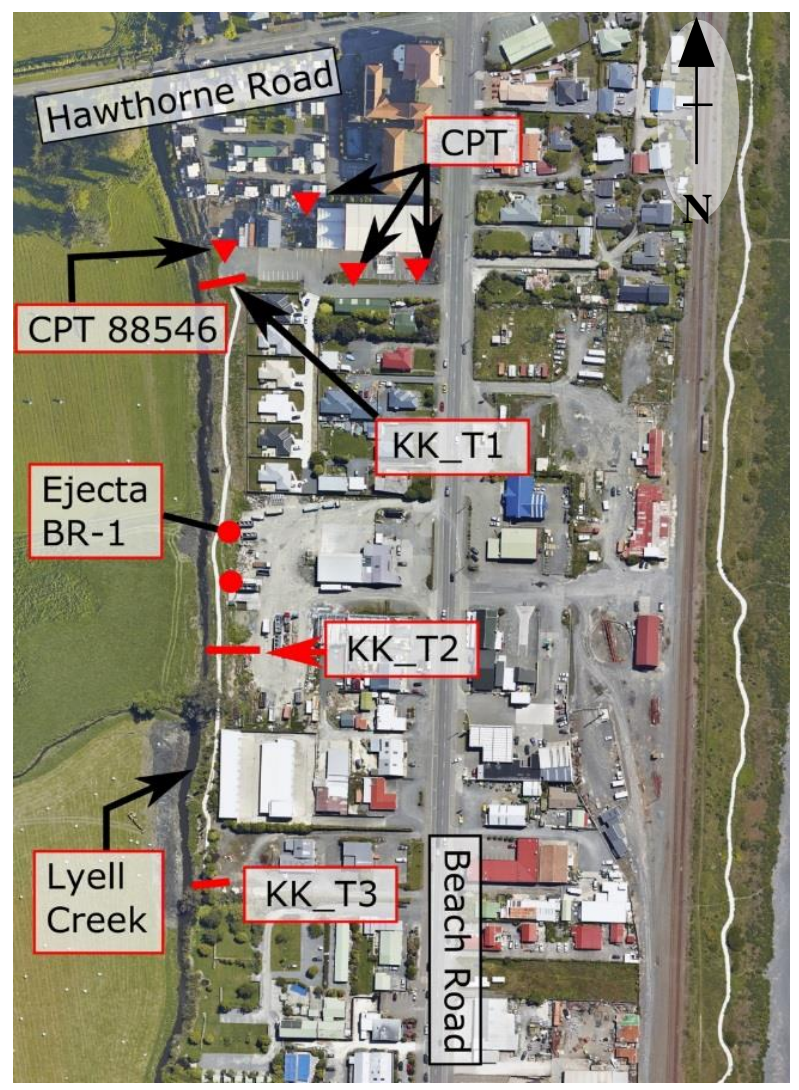

Figure 35: Location of CPT and Transects along Lyell Creek (Approx. coord. of centre of image: $-42.391^{\circ}, 173.679^{\circ}$. Basemap: LINZ).

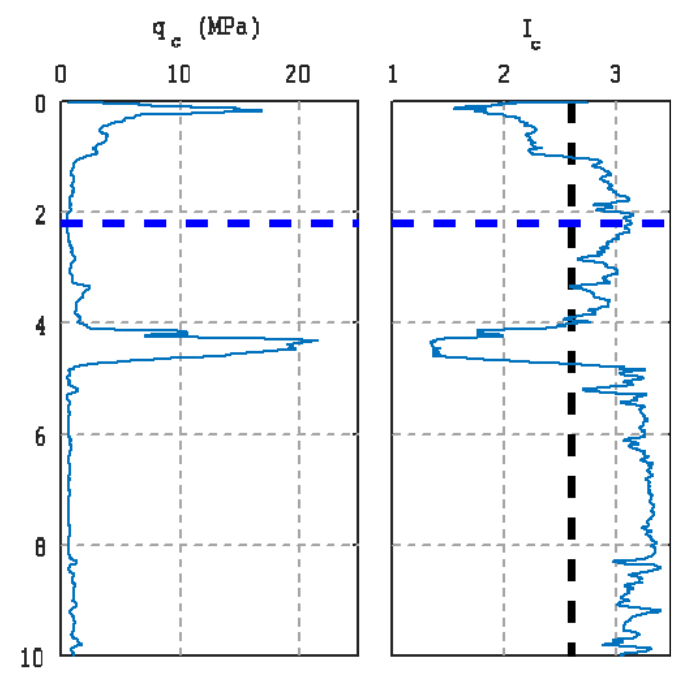

Figure 36: CPT_88546 sounding 15 m east of Lyell Creek $\left(-42.3901^{\circ}, 173.6777^{\circ}\right.$. NZGD [26]).

Very close to this area, small patches of ejecta were observed $15 \mathrm{~m}$ east of the creek; the PSD for this sample (BR-1) is shown in Figure $41 \mathrm{~b}$ and is noticeably much finer, classifying as Silt (ML) per ASTM D2487-11 [27], than the ejecta collected at other sites in Kaikōura as well as sites in both the Waiau and Blenheim areas.

The lateral ground displacements at Lyell Creek heavily affected the Hawthorne Road bridge, which is pictured in Figure 37 and Figure 38. At this location, lateral ground movements towards the river were of the order of $1 \mathrm{~m}$, and concentrated within $15 \mathrm{~m}$ of the river channel. This short-span bridge showed distress at both ends, with clear rotation of both abutments reminiscent of the "back-rotation" observed in Christchurch during the 2010-2011 earthquake sequence [24, 28]. The deformations occurring at the abutments resulted in large movement of the bridge deck, both in plan (creating the gap shown in Figure 38c), and vertically at the eastern abutment (Figure 38e). The deck beams detached from their anchor points and displaced significantly, as shown in Figure $38 \mathrm{f}$. It should be noted that the bridge orientation is slightly skewed (in plan) relative to the creek, and it is possible that the large deck displacements arise partly from the bridges' skew. Despite the large cracks which were visible (particularly on the east side of the bridge), no liquefaction ejecta was observed in the surrounding soil, while a borelog from a nearby water well indicated that the soil profile is typically fine-grained.

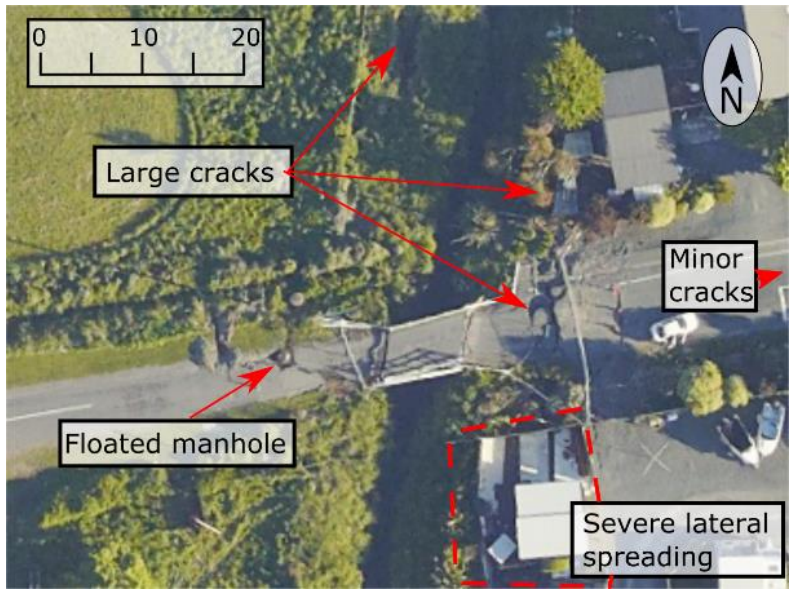

Figure 37: Overview of Lyell Creek bridge crossing at Hawthorne Road (Approx. coord. of centre of image: $\left.-42.389^{\circ} ; 173.677^{\circ}\right)$.

Two instances of retaining wall failures were observed towards the southern end of Lyell Creek (Figure 39). In both cases, the retaining walls were timber structures and had visibly bulged towards the creek, with cracking apparent in the retained soil behind the wall.

\section{Liquefaction in Rural Kaikōura}

Minor to moderate liquefaction ejecta was observed in a relatively small number of locations, generally west of the main Kaikōura town in locations that appear to be associated with paleo channels. Figure 40 shows a site that is representative of the maximum severity in terms of surface manifestation in Kaikōura. A map showing the location where ejecta were observed is presented in Figure 41a and the PSD of ejecta samples from the locations marked BR-1 (discussed previously) and SR-1 are shown in Figure 41b. The amount of liquefaction ejecta at each of the recorded locations was generally quite limited, and affected only a few properties due to its spatial location. At the houses which were located close to the liquefaction ejecta, it appeared that most suffered settlements less than $10 \mathrm{~cm}$; at one location however, lateral ground displacement towards a paleo channel caused vertical cracking within the house as shown in Figure 42. 


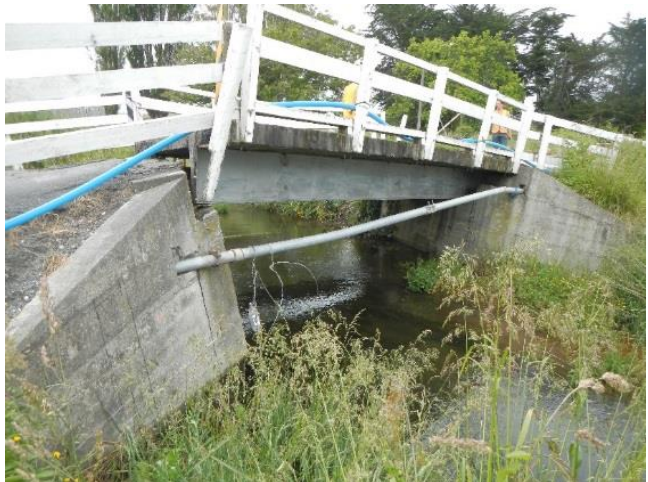

(a)

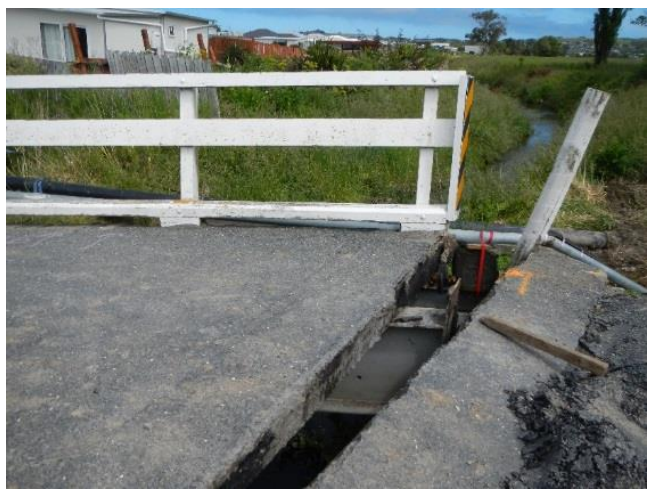

(c)

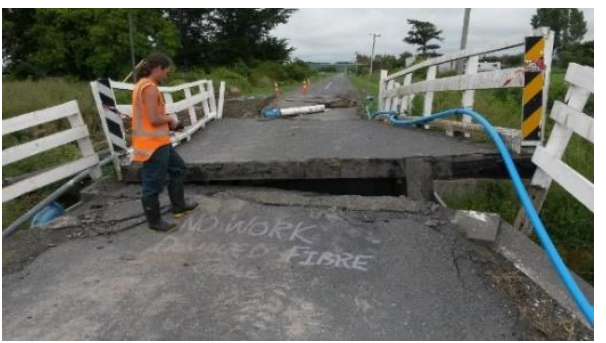

(e)

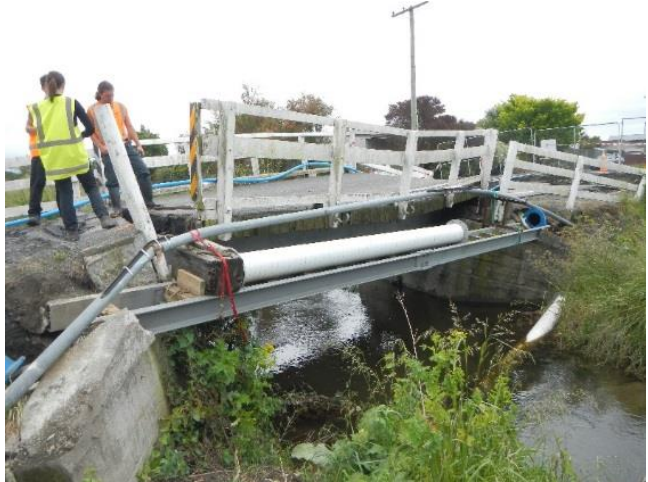

(b)

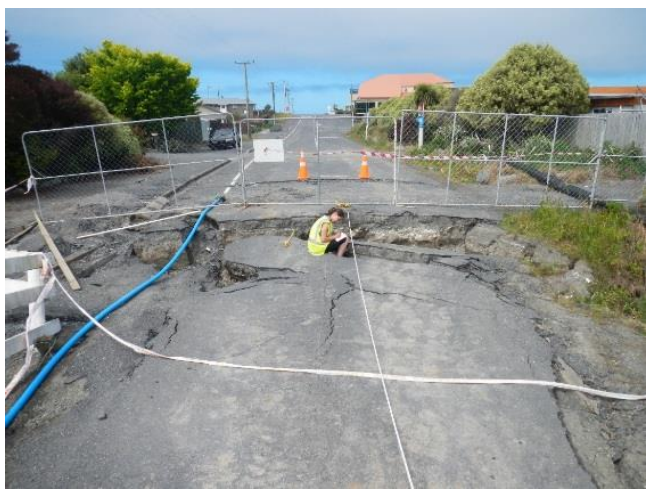

(d)

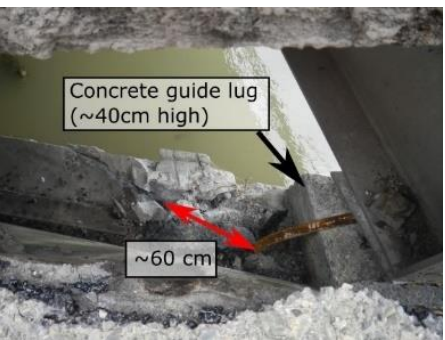

(f)

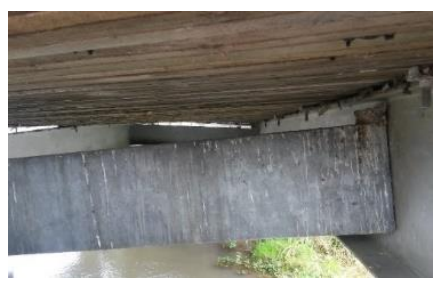

(g)

Figure 38: Severe damage at Hawthorne Road bridge $\left(-42.389^{\circ}, 173.677^{\circ}\right):($ a) North side of Hawthorne Rd. bridge. Note the abutment rotations and the deck displacements; (b) South side of Hawthorne Rd. Bridge; (c) Gap between deck slab and west abutment (taken facing S); (d) Cracking in the eastern approach to the bridge (taken facing E); (e) Vertical displacment of deck slab (taken facing W); (f) Pull-out of deck beam restraint at the east abutment (taken facing W); and (g) Twisting of the deckbeam (taken facing $W$ ).

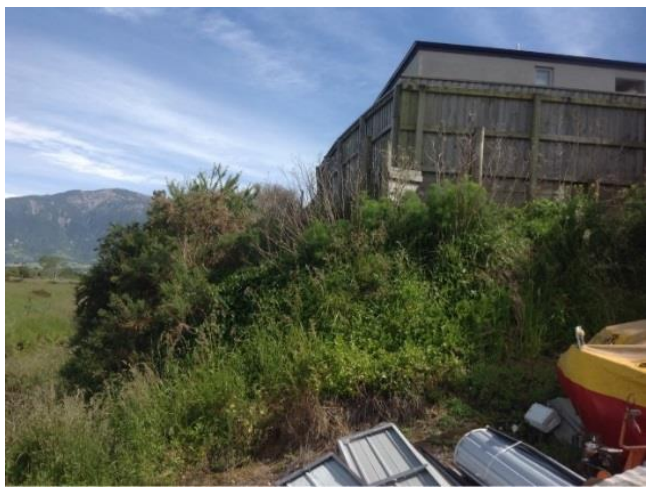

(a)

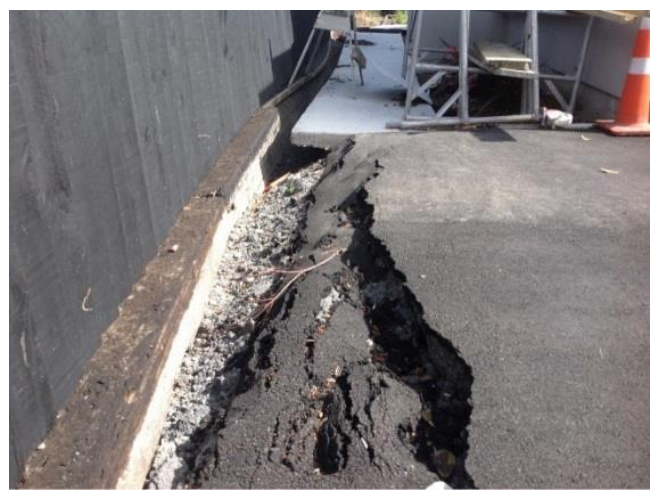

(b)

Figure 39: (a) Failure of a retaining wall on Beach Road $\left(-42.3973^{\circ}, 173.6798^{\circ}\right.$, taken facing $\left.N\right)$. (b) Cracks behind the retaining wall on Beach Road $\left(-42.3971^{\circ}, 173.6798^{\circ}\right.$, taken facing $\left.N\right)$. 


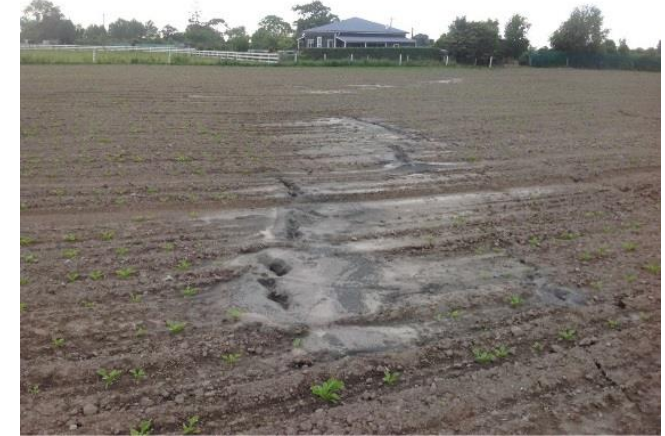

Figure 40: Liquefaction ejecta in the field south of Mill Road. The ejecta are concentrated in lines which continue in the background over a total length of $\sim 100 \mathrm{~m}\left(-42.3772^{\circ}\right.$, $173.6753^{\circ}$, taken facing $S E$ ).

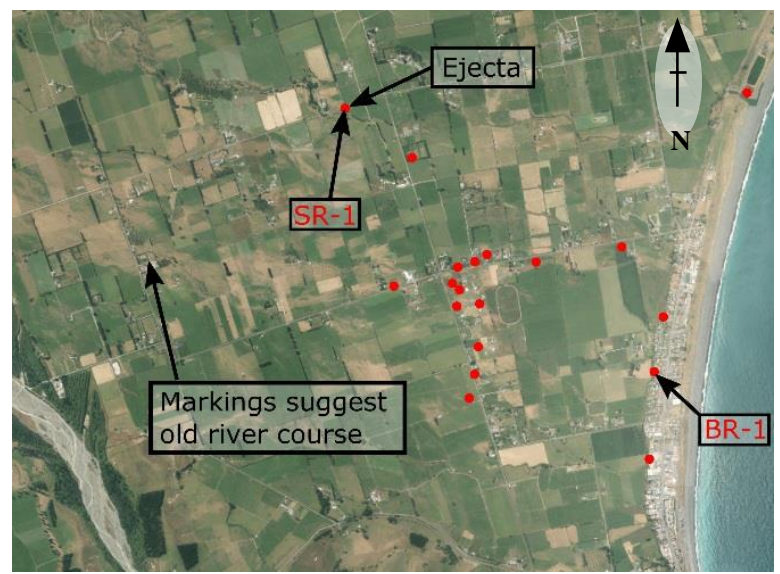

(a)

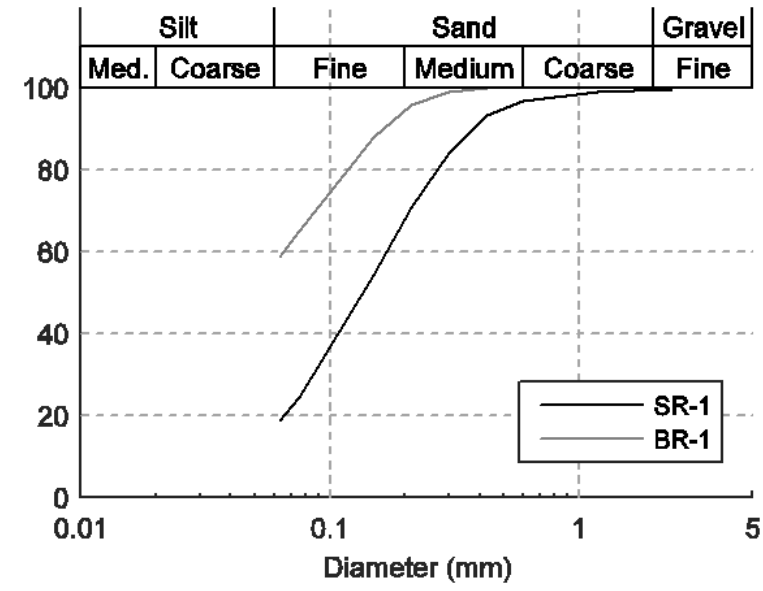

(b)

Figure 41: (a) Positions of known liquefaction ejecta. SR-1 and BR-1 refer to locations where ejecta samples were obtained. (Approx. coord. of centre of image: $-42.375^{\circ}$,

$173.647^{\circ}$ ). Basemap: LINZ . (b) Particle size distributions of ejecta samples $S R-1$ and BR-1.

\section{Wastewater Treatment Facility}

The wastewater treatment facility for Kaikoura is located north of the town, next to the beach. The earthquake caused differential settlements and ground cracking. Some ejecta was recorded at the northern end of the main pond, while additional ejecta were observed just south of the facility, close to one of the piers of the railway bridge running along the west edge of the facility. The ground deformations at the site were sufficient to cause tearing in the liner of the most southerly pond (marked KK-OPS in Figure 43), as well as causing some of the aeration posts to fail and rotate inward toward the pond (Figure 44a and Figure 44b). Some failures in the concrete lining of the main pond were also observed as shown in Figure $44 c$.

\section{AMURI AND EMU PLAINS}

The Amuri and Emu Plains (lying to the south and north of the Waiau River respectively) comprise the relatively flat bottomed Waiau valley in North Canterbury bounded to the north by the Amuri Mountain range and the Lowry Mountain range to the south and east. The area is rural, with two small towns (Rotherham and Waiau) located towards the north-east end of the valley. Waiau is the larger of the two towns and has a population of $\sim 260$ [11]. It is located at the north-east of the valley, at the confluence of the braided Waiau and Mason Rivers. Additional townships are located within this valley, but the have similarly small populations.

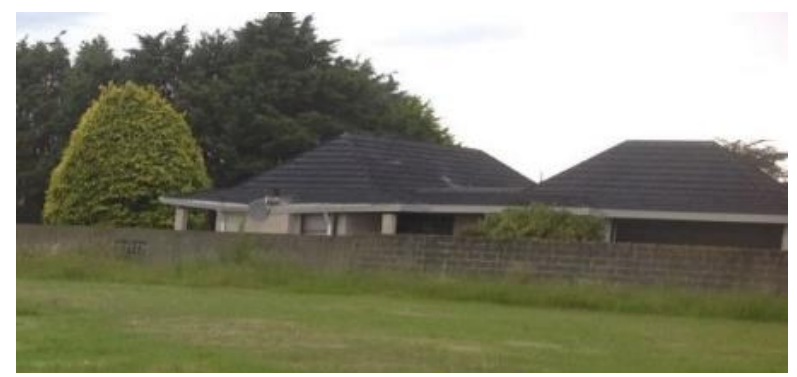

Figure 42: Damage caused to house on Mill Road by lateral ground movements $\left(-42.3784^{\circ}, 173.6675^{\circ}\right.$, taken facing $\left.\mathrm{NE}\right)$.

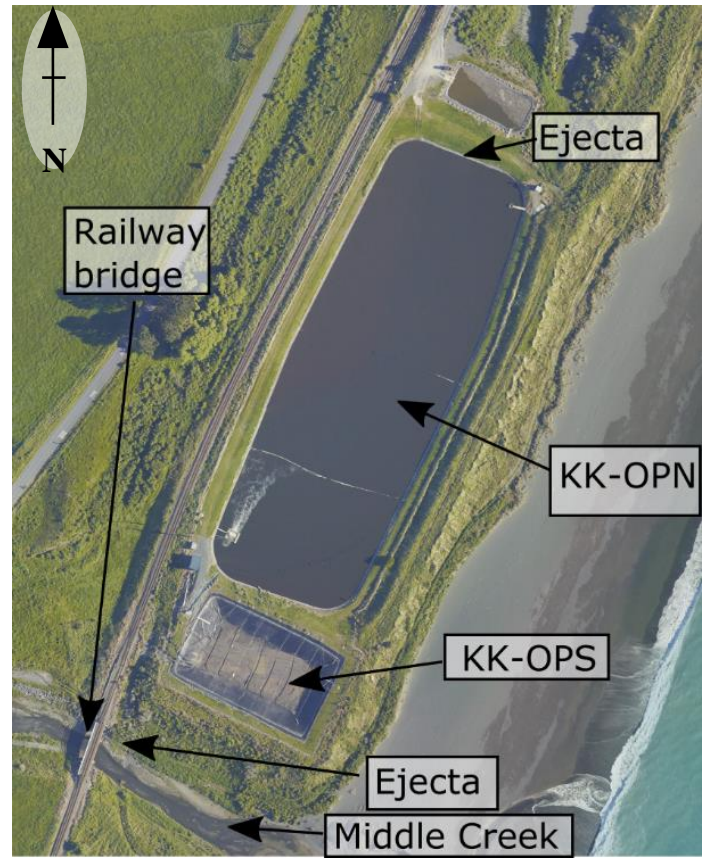

Figure 43: Overview of Oxidation Ponds north of Kaikōura (Approx. coord. of centre of image: $-42.366^{\circ}, 173.688^{\circ}$. Basemap: LINZ). 


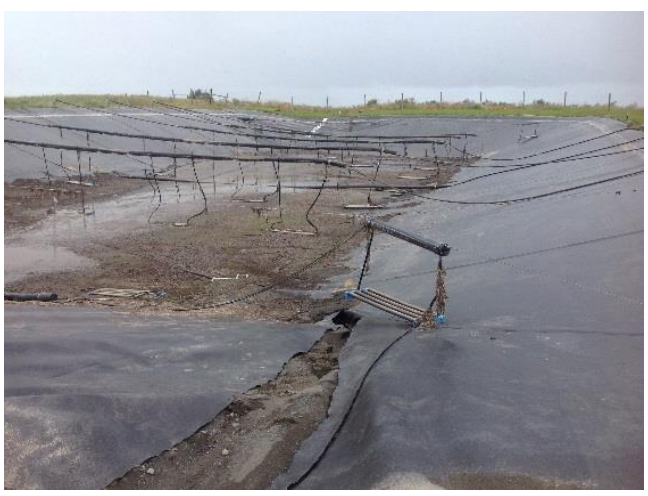

(a)

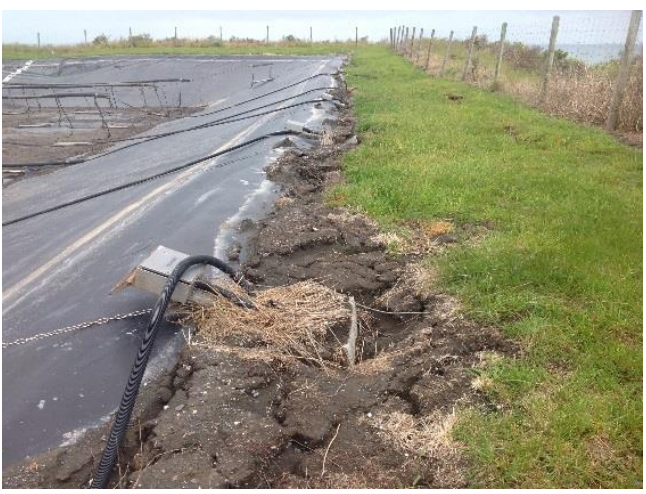

(b)

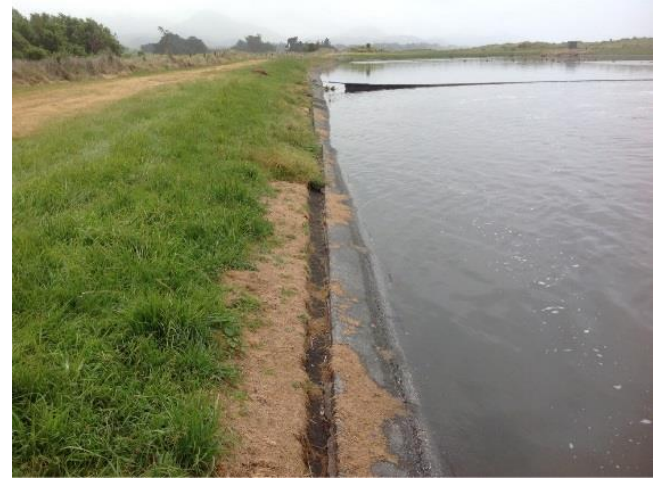

(c)

Figure 44: (a) KK-OPS looking from the SW corner. Note: Geoliner in the foreground has ripped $\left(-42.3668^{\circ}, 173.6865^{\circ}\right.$, taken facing $E)$. (b) Rotation of the aeration-line control posts on the south side of KK-OPS $\left(-42.3669^{\circ}, 173.6867^{\circ}\right.$, taken facing E). (c) West edge of KK-OPN. Note concrete panel has displaced into pond $\left(-42.3660^{\circ}, 173.6868^{\circ}\right.$, taken facing $\left.N\right)$.

The township of Waiau is built upon alluvial fill sequences, predominantly comprised of gravels, associated with Pleistocene glaciation and the subsequent outwash surface, and the later development of the Waiau River [29]. Much of the overbank flood-plain surrounding the Waiau River is used as farmland and is underlain by alluvial gravels with localised sand lenses and capped by over-bank silts. Smaller active and paleo-stream channels are present within the flood plain, along with paleo-channels of the Waiau River which are recognizable as topographic depressions within the farmland. The active and paleo-channels are likely comprised of alluvial gravels and sands.

The sequence of fault ruptures associated with the Kaikoura earthquake began relatively close to the township of Waiau and propagated in a north-easterly direction. The WTMC strong motion station, located $\sim 4 \mathrm{~km}$ north of Waiau town (position marked in Figure 45), indicated that this region experienced extremely strong shaking, with horizontal accelerations in excess of $1 \mathrm{~g}$, and vertical accelerations of up to $2.7 \mathrm{~g}$. Evidence of the strong ground motions in this regions included broken wooden power pylons (observed in Waiau and along River Road), clear displacement of large stone blocks in Waiau, and the toppling of gravestones in the town of Rotherham.

Reconnaissance in this area was undertaken relatively soon after the earthquake, with the first exploratory visit to the region taking place on the $15^{\text {th }}$ November 2016 (in conjunction with wider preliminary reconnaissance undertaken by practicing engineers). Additional visits occurred on the $17^{\text {th }}$ and $18^{\text {th }}$ November 2016. The extent of damage in this area was not well-known immediately, and the reconnaissance on the $15^{\text {th }}$ November 2016 aimed only to see as much as possible to assess the levels of earthquake related damage. The additional trips on the $17^{\text {th }}$ and $18^{\text {th }}$ November focussed on the town of Waiau and the surrounding bridges. Most of the reconnaissance in these regions involved drive-through surveys, and it was not logistically possible to access most areas away from the main roads. The routes covered during the reconnaissance are shown in Figure 45.

Damage to buildings and infrastructure in this region was largely caused by the high inertial loads. Due to the sparse population in the area, the building stock throughout the town of Waiau is largely single storey, light residential buildings that experienced damage to brick facades, unreinforced masonry walls, and fallen chimneys, examples of which are shown in Figure 46. The main damage to infrastructure in the region was to the multi-span bridges crossing the Waiau, Mason, and Wandle Rivers. At some of these bridges, the inertial loading caused severe structural damage as discussed by Palermo et al. [29]. Common geotechnical issues included settlement and outward cracking of the approaches, while abutment rotation and cracking was observed at a small number of bridges. Liquefaction was observed in some locations (shown in Figure 45), but was generally not widespread in the surveyed areas. Major liquefaction-induced lateral spreading was not observed by the reconnaissance teams but it may have contributed to some of the bridge abutment damage and road cracking.

It is important to state that surface expressions of fault rupture were present in the region, and in particular, part of the rural Leslie Hills Road was completely destroyed by a rupture transverse to the road (Figure 47). In this same area, there were both tension cracks and compressional features, the latter of which was made obvious by sagging fence lines and by ridges in the road surface. 


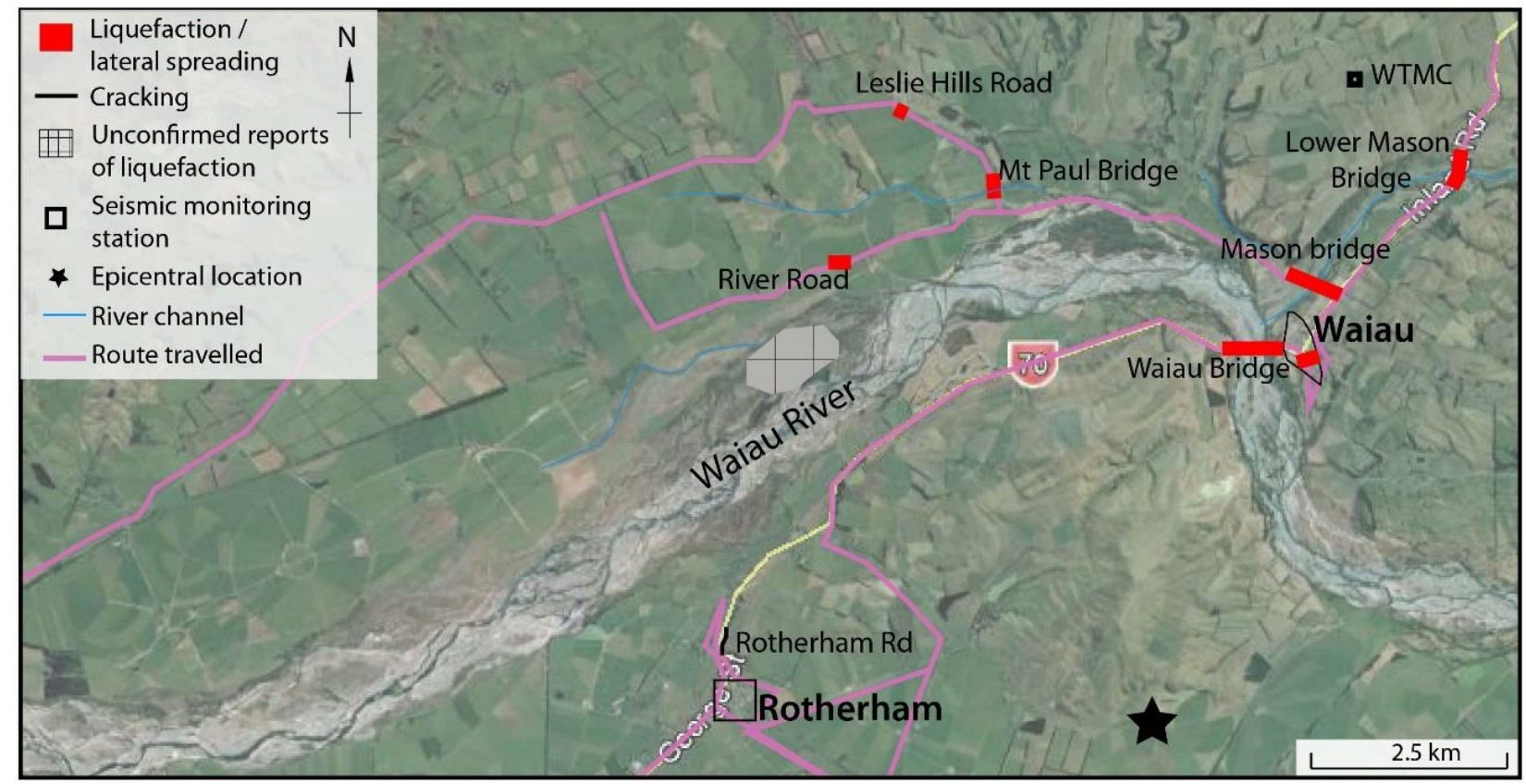

Figure 45: Map of the Waiau area indicating areas with liquefaction manifestation (Approx. coord. of centre of image: $-42.658^{\circ}$, $173.005 \%$.

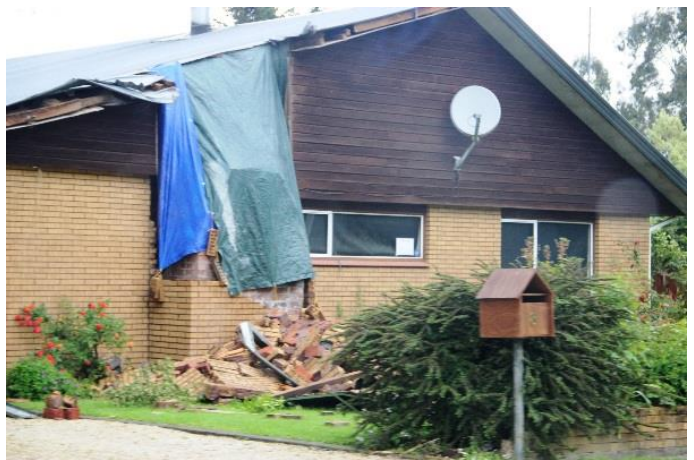

(a)

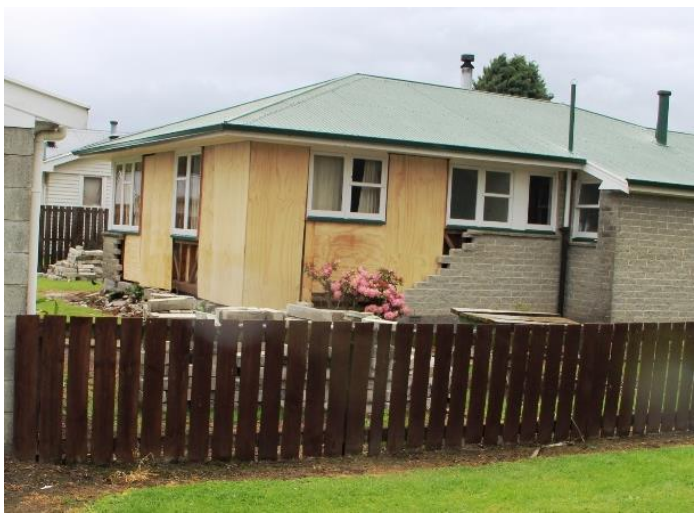

(b)

Figure 46: Examples of damage to residential buildings in Waiau township (Approx. coord: $\left.-42.66^{\circ}, 1^{173.04}{ }^{\circ}\right):($ a) fallen chimney; (b) damage to brick façade.

\section{Liquefaction and Ground Damage within Waiau Township and Rural Areas}

Despite the high ground shaking experienced within the town, there were very few geotechnical impacts within the town of Waiau. Minor evidence of liquefaction was observed in a few places at the south of the town, though there were additional reports (which could not be verified) of more extensive liquefaction in a paddock between the town and the Waiau River at the southern end of the town. Liquefaction was observed in the agricultural areas close to the Waiau River, west of Waiau town. Aerial photography of this area (Figure 48) shows standing water and ejecta in the fields as well as on the roads and ground teams confirmed the presence of ejecta on the River Road at the location marked in Figure 45.

Samples of ejecta were taken from a sand boil within Waiau town, as well as a minor sand boil close to the fault rupture on Leslie Hills Road. The particle size distributions of these samples are shown in Figure 49 and indicate the ejecta material is relatively clean fine sand. Also shown in this figure are the gradings associated with ejecta material found near the river at the multi-span bridges which will be discussed subsequently. It should be noted that the ejecta recovered from the river channels is much coarser than the ejecta recovered both in Waiau town, and elsewhere (i.e. in Blenheim and Kaikōura).

Ground cracks were periodically observed on the roads leading towards Waiau, particularly on the rural farming roads north of the Waiau River. Ground cracks were most often relatively well aligned with the road and most commonly ran along the outer edges of the road. In some cases, cracks were $20-30 \mathrm{~cm}$ wide, and several metres long. Examples of the ground cracking encountered are shown in Figure 50, and are representative of the most severe observed damage of this type. Within the town of Waiau, a number of cracks were observed both parallel and perpendicular to the road. These cracks typically had little impact on the serviceability of the road, being only a few centimetres wide in most cases and with similarly small vertical offsets. 


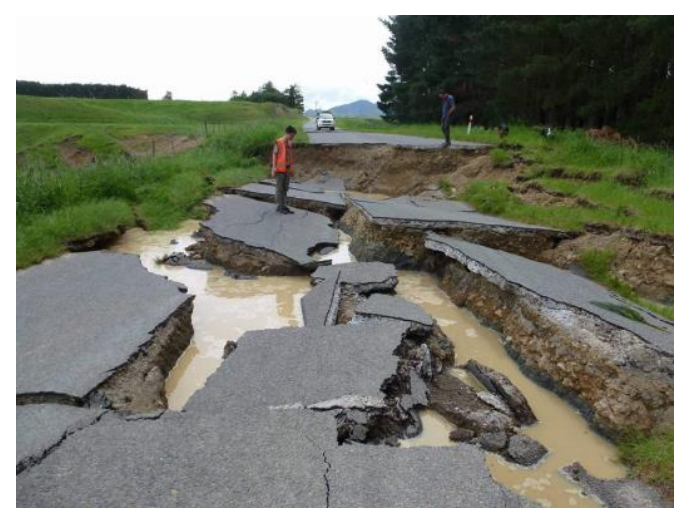

Figure 47: Damage to Leslie Hills road caused by fault rupture (Approx. coord: $-42.631^{\circ}, 172.990^{\circ}$, taken facing $W$ ).

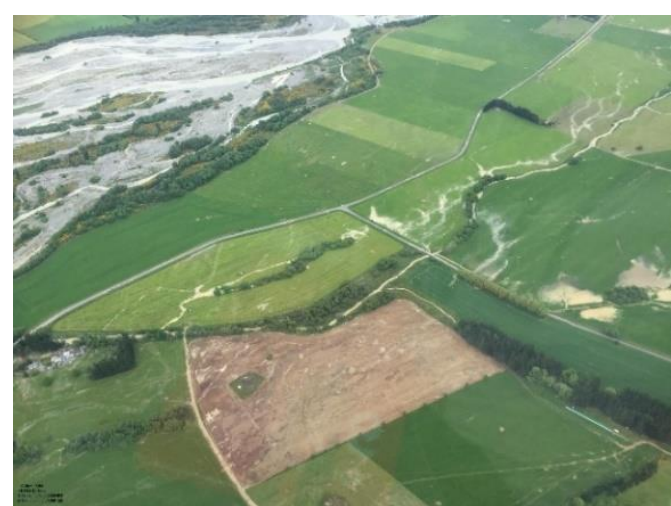

Figure 48: Standing water and ejecta west of Waiau town $\left(-42.638^{\circ}, 172.993^{\circ}\right)$.

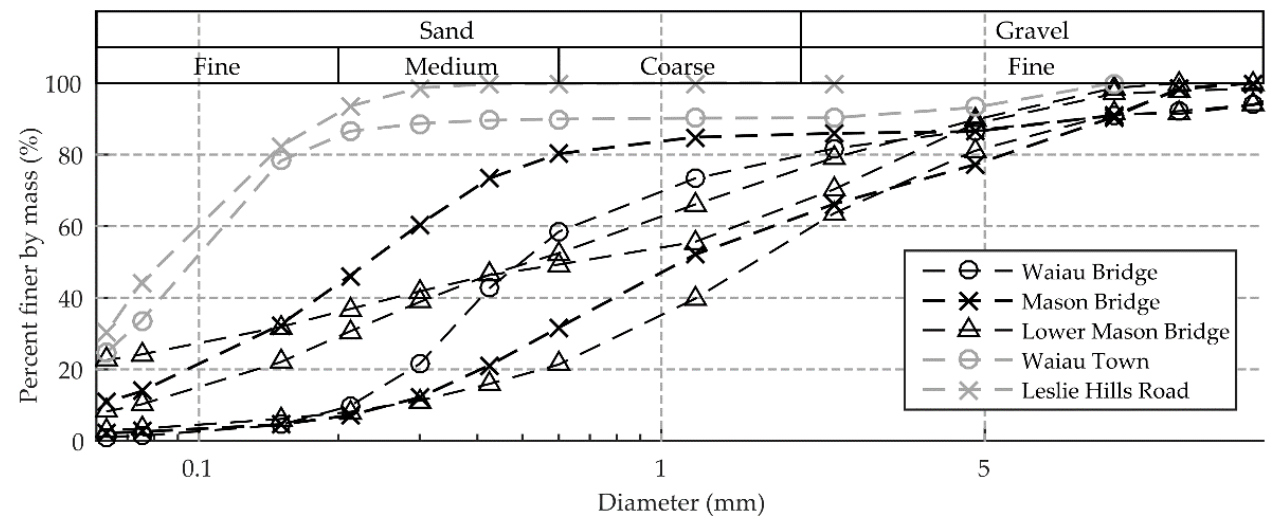

Figure 49: Particle size distribution of ejecta samples collected across the Amuri and Emu Plains.

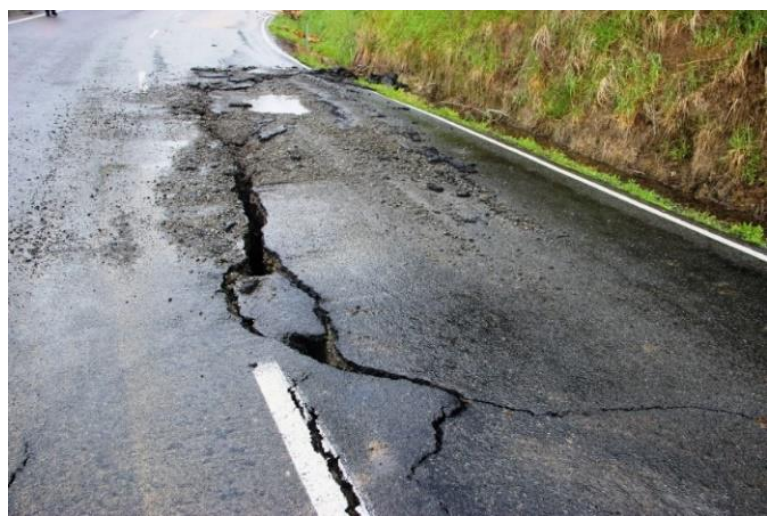

(a)

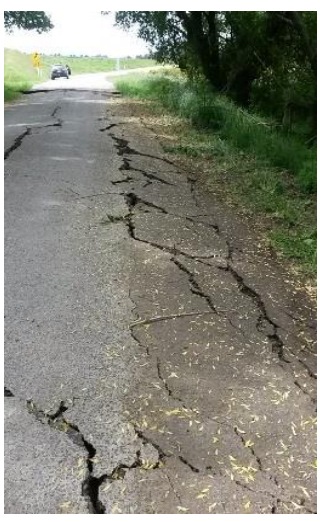

(b)

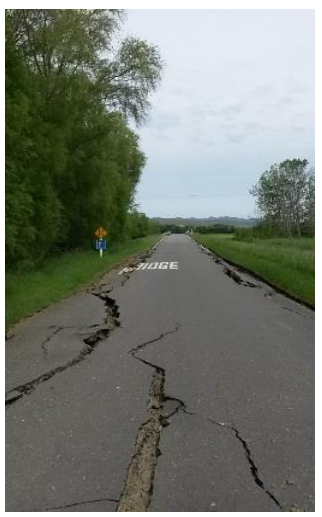

(c)

Figure 50: Cracks parallel to the road. (a) crack on SH70, north of Rotherham $\left(-42.690^{\circ}, 173.946^{\circ}\right.$, taken facing NE); (b) cracks on Leslie Hills Road just after small bridge crossing $\left(-42.639^{\circ}, 172.915^{\circ}\right.$, taken facing E); crack on Leslie Hills Road close to fault rupture area $\left(-42.634^{\circ}, 172.992^{\circ}\right.$, taken facing $\left.S\right)$.

\section{Impact on Bridges}

Geotechnical related damage, including settlements and outward spreading of the approaches, affected a number of bridges in the area surrounding the town of Waiau. However, as previously stated, structural damage at these bridges was a result of the high inertial loading, with effects related to liquefaction and lateral spreading generally being secondary in overall importance.

The Waiau River Bridge is a 33-span reinforced concrete bridge located just west of the Waiau township as shown in Figure 45. Moderate amounts of liquefaction ejecta were observed at the toes of the approach embankments and in the river banks ahead of the abutments, as well as being visible around unsubmerged bridge piers (Figure 51a). Some minor lateral spreading cracking was visible on both sides of the river and in the bridge approaches as shown in Figure 51b. On the west approach, there was $\sim 20 \mathrm{~cm}$ of outward spreading and about $40-50 \mathrm{~cm}$ of settlement (Figure 51c). As shown in Figure 51d, the western abutment wall rotated (base moving towards the river), opening up some large cracks in the centre of the wall. At the second pier from the west end of the bridge, visible deformation in the bridge deck was observed (Figure 51e), as a result of some (clockwise) twisting in plan, as well as differential settlements in the N-S direction. The approach deformation on the eastern side was more modest, with $\sim 10 \mathrm{~cm}$ of outward spreading and $20 \mathrm{~cm}$ of settlement. Despite the cracking and apparent movements, the overall impact of liquefaction and lateral spreading was very low, with the bridge remaining open to reduced speed traffic after the earthquake. 


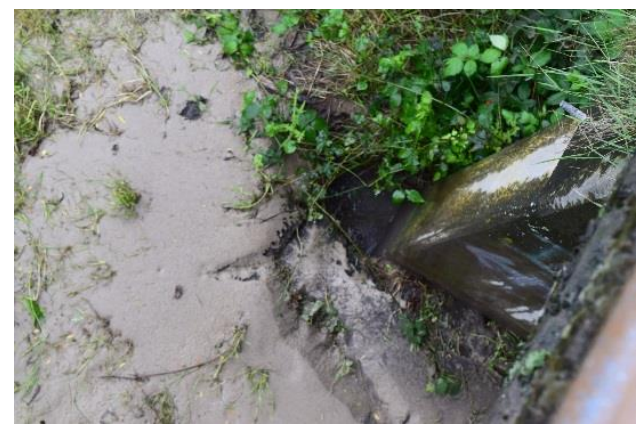

(a)

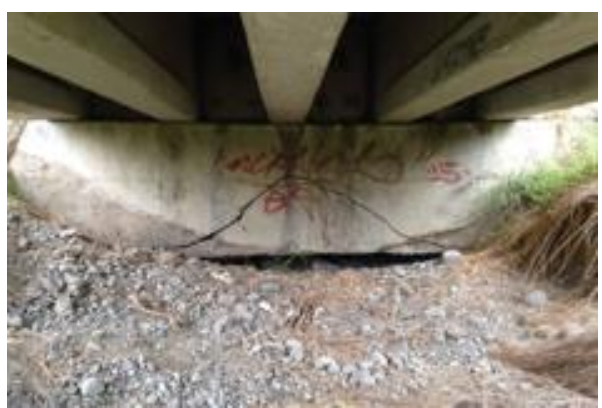

(d)

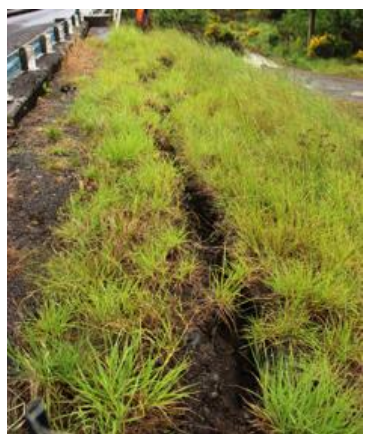

(b)

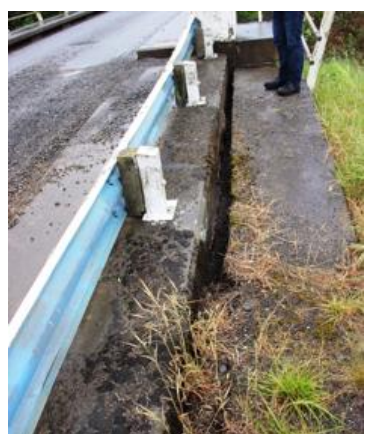

(c)

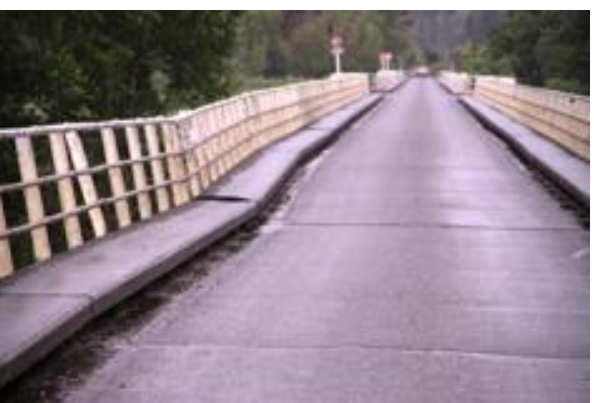

(e)

Figure 51: Liquefaction-induced damage at Waiau River Bridge $\left(-42.66^{\circ}, 173.03^{\circ}\right):($ a) Moderate liquefaction and gap (from inertial loading) around bridge pier; (b) Lateral cracking in southern side of western approach embankment looking E; (c) Settlement at outward movement at western abutment looking $E ;(d)$ Cracking and subsidence of fill at river side of western abutment looking W; (e) Differential settlement at second pier from western abutment looking $E$.

The Lower Mason Bridge is a 165-m long, 8-span reinforced concrete bridge located on the Inland Road about $3 \mathrm{~km} \mathrm{NE}$ of Waiau township. Evidence of liquefaction was observed on the unsubmerged parts of the gravelly river channel (Figure 52a), as well as just north of the river (i.e. on the floodbank); the ejecta material was gravelly sand (PSD shown in Figure 49). It should be noted that the river occupied the southern portion of its channel at the time of the reconnaissance, so any ejecta at the south end of the bridge was not visible. Reasonably minor lateral spreading cracks were observed in the river banks, and outward spreading and settlement of the approaches occurred. Cracking in the embankments indicate at least $40 \mathrm{~cm}$ of outward deformation occurred in the fill material behind the abutment walls as shown in Figure 52b. The marks on the abutment walls were used to estimate the settlement of the embankment. The measurements indicate 50$60 \mathrm{~cm}$ of settlement on the river side of both abutments (example from northern abutment is shown in Figure 52c), and at least $30 \mathrm{~cm}$ of settlement on the approach side. Despite the settlement and cracking in the approaches, the bridge was not really impacted by the liquefaction and lateral spreading at the site, but rather by the extreme inertial loading which caused reasonably large permanent deformation (visible in the location of the buckled crash barrier in Figure 52d), the unseating of the deck from the rubber bearings at the abutments, and the plastic hinging which is visible in Figure 11e and discussed in further detail in Palermo et al [30].

The Mt Paul Bridge is a 19-m long, single span, precast concrete bridge on the rural Leslie Hills Road located only a few hundred metres SE of the fault rupture previously mentioned. The damage observed at the Mt Paul Bridge is a particularly severe example of the typical rural bridge damage observed in this area. As shown in Figure 12, significant lateral cracking and settlement occurred in both approaches. Some of the cracks shown are $\sim 20-30 \mathrm{~cm}$ wide, and the cumulative outward movement is about $40-50 \mathrm{~cm}$. The settlements relative to the deck on the approach side are also $\sim 40-50 \mathrm{~cm}$. Settlements and stream-ward spreading was also evident on the stream side of both abutments as shown in Figure 12 (c-d). This settlement has exposed the base of the abutments on both sides of the bridge, revealing some severely damaged piles on the southern side.

\section{CHRISTCHURCH AND SURROUNDING AREA}

Christchurch is New Zealand's $3^{\text {rd }}$ largest city in terms of population, which was around 340,000 in 2013 [11], and lies approximately halfway down the east coast of the South Island. The city is located south of the fault ruptures associated with the Kaikōura earthquake and experienced relatively low peak ground accelerations, with the largest recordings showing around $0.08 \mathrm{~g}$ in Kaiapoi and $0.04 \mathrm{~g}$ within Christchurch itself.

Low peak accelerations were recorded by the strong motion stations within Christchurch and were considered unlikely to cause any significant damage. However, given the repeated liquefaction during the main shocks of the 2010-2011 Canterbury Earthquake Sequence, as well as relatively minor events such as the 2016 Valentine's Day earthquake, it was decided to investigate whether there were any signs of fresh liquefaction ejecta at sites that experienced severe liquefaction in previous events [17]. Four sites were selected: Swindells Road in Waikuku Beach $\left(-42.2839^{\circ}, 172.7180^{\circ}\right)$; Cassia Place in Kaiapoi $\left(-43.3851^{\circ}, 172.6704^{\circ}\right)$; Atlantis Street in New Brighton $\left(-43.4956^{\circ}, 172.7038^{\circ}\right)$; and Seabreeze Close in Bexley $\left(-42.5184^{\circ}, 172.7203^{\circ}\right)$. At all of these sites, there was no indication that liquefaction had occurred during the Kaikoura earthquake, and on this basis it was decided not to carry out any additional reconnaissance. 


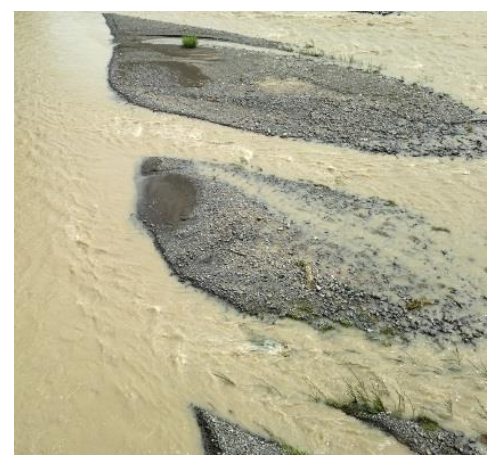

(a)

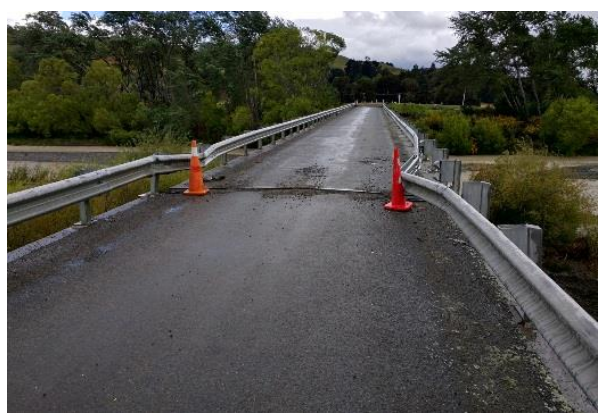

(d)

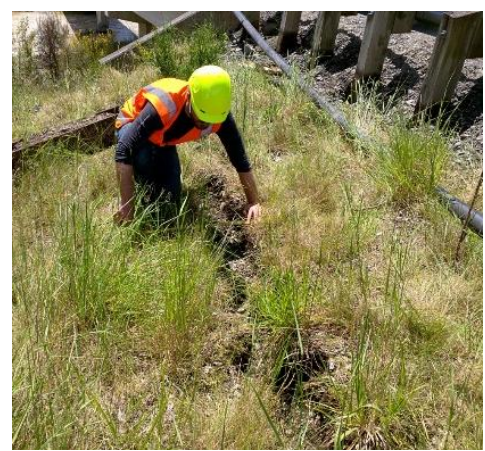

(b)

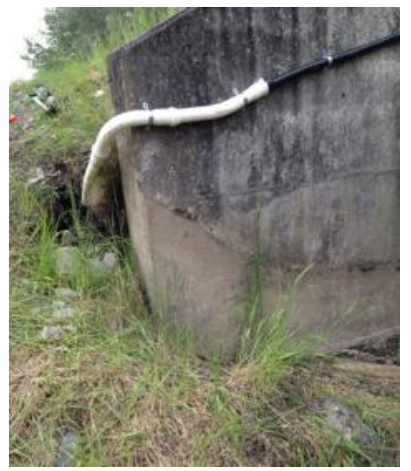

(c)

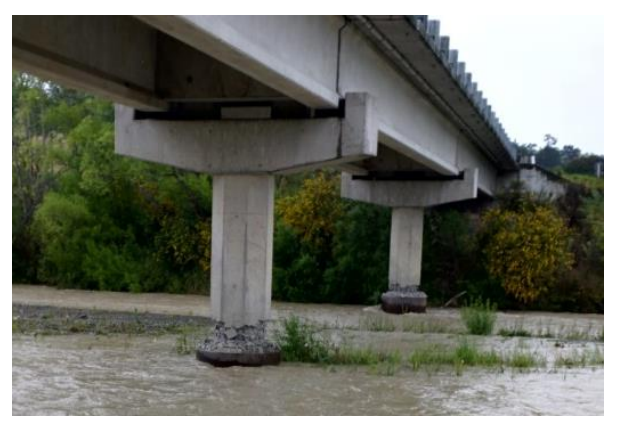

(e)

Figure 52: Liquefaction, deformation and damage at the Lower Mason Road Bridge (Approx. Coordinates: $\left.-42.63^{\circ}, 173.07^{\circ}\right):($ a) Ejecta within the braided river channel (taken facing $W) ;(b)$ Large outward spreading $(40$ cm) at the west side of the south approach (taken facing $N$ ); (c) Settlement of fill materials at west side of north abutment (taken facing $N$ ); (d) Lateral displacment of bridge deck relative to the abutment and buckling of crash barrier (taken facing $S$ ); (e) Structural damage at the base of the bridge piers.

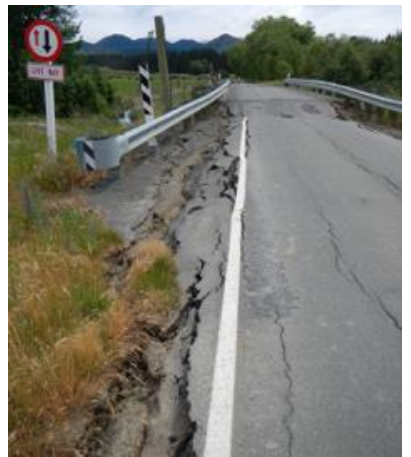

(a)

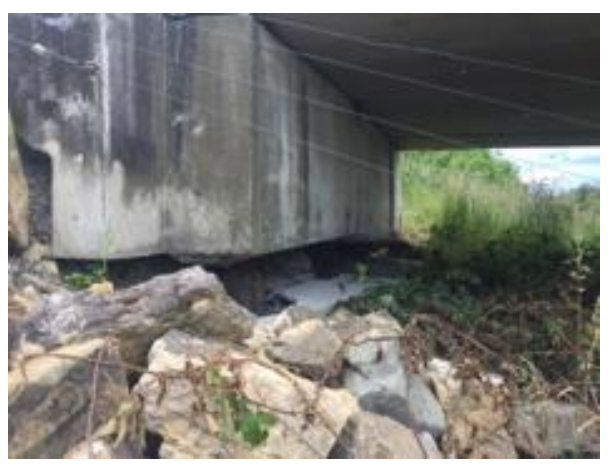

(c)

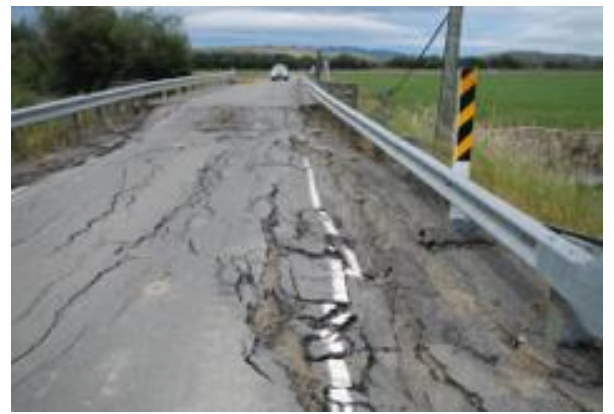

(b)

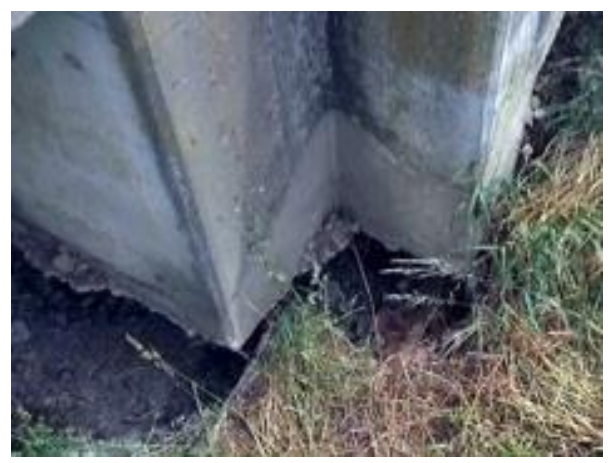

(d)

Figure 53: Settlement and cracking in approaches to Mt Paul Bridge $\left(-42.64^{\circ}, 172.99^{\circ}\right):$ (a) $S W$ corner looking $N(d) N W$ corner looking S. (c) Settlement and spreading of fill on north (stream) side of southern abutment (looking W) exposing severely damaged piles; (d) Settlement and soil gapping on eastern side of north abutment facing $N$. 
However, a minor liquefaction feature in the Parklands area of Christchurch City was brought to the authors attention [31], a photo of which is shown in Figure 54. Upon further investigation by the authors, the ejecta was located very close to the water connection boxes, and may have resulted from the liquefaction of loose back-fill material. Minor liquefaction may have also occurred in isolated areas, but if so, the impacts of these episodes were negligible.

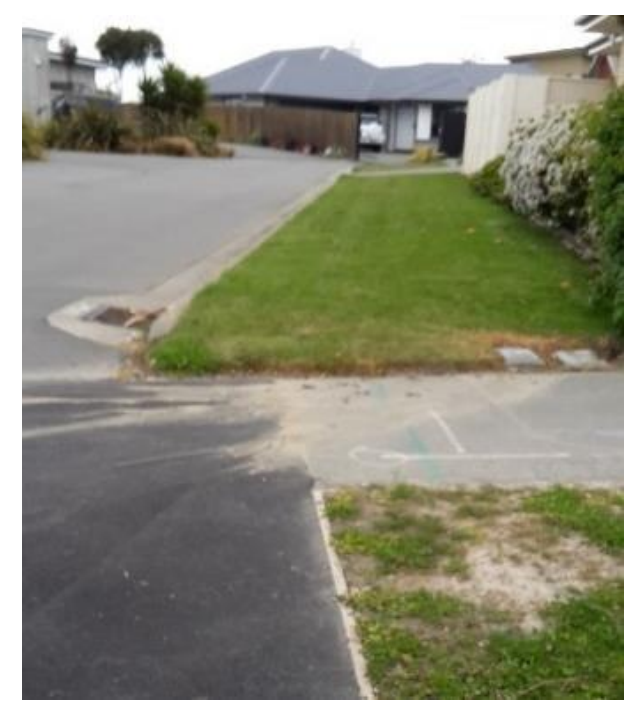

Figure 54: Isolated ejecta in the Parklands area of Christchurch (Approx. coord: $-43.47^{\circ}, 172.71^{\circ}$; Photo courtesy of $S$. Cox).

\section{SUMMARY AND CONCLUSIONS}

The Mw7.8 Kaikōura earthquake involved the rupture of multiple faults in the Marlborough Fault Zone and caused widespread disruption in the north-east region of the South Island of New Zealand. Despite the large magnitude of the earthquake and high ground accelerations, relatively limited liquefaction and ground damage was observed in the Waiau Valley (where ground motions were strongest) and in the townships of Blenheim and Kaikōura.

Severe manifestations of liquefaction and lateral spreading were observed within the floodplains of the Lower Wairau and Opaoa Rivers in the area the north and east of Blenheim township. Very few structures exist in this area, hence the immediate impact of these movements was negligible to infrastructure. The locations worst affected correspond with abandoned channels or inner meander bends of the rivers. Stopbank damage occurred in locations where they crossed younger deposits in paleo channels, resulting in heavy cracking and slumping in the direction parallel to the paleo channel. Damage within the township of Blenheim was restricted to a small number of locations, and the impact on structures was low.

Significant damage occurred to a limited number of residential structures and two retaining walls in the town of Kaikōura, due to large ground movements which occurred in a concentrated zone within 30m of Lyell Creek. Ejecta was not a common feature along the creek, and it is likely that soft silty/clayey materials in the upper soil profile are responsible for the movements. The wastewater treatment facility located just north of Kaikōura also suffered damage as a result of ground movements, which included tears in the liners of the oxidation ponds and distortions in the aeration system.

The impacts of liquefaction and general ground distress across the Amuri and Emu Plains of the Waiau Valley were extremely modest given the large peak accelerations observed in the area (i.e., horizontal accelerations of $\sim 1 \mathrm{~g}$ ). The most significant impacts to the infrastructure in this area were the result of high inertial loading (e.g. structural damage to some of the bridges). Liquefaction and lateral spreading was observed at some bridge sites, but the impact and damage was generally secondary to those arising from the inertial loads. Characteristic damage to the bridges included settlement of the approach fills, outward cracking of the approach embankments, and some limited back-rotation of the bridge abutments.

No evidence of liquefaction was observed at 4 sites (located in Christchurch, Kaiapoi and Waikuku Beach) where visible manifestation of liquefaction had occurred in many of the events of the 2010-2011 Canterbury Earthquake Sequence.

\section{ACKNOWLEDGEMENTS}

The primary support in the reconnaissance effort for the NZ members was provided by QuakeCoRE and the Earthquake Commission (EQC). This is QuakeCoRE publication number 0144. The primary support for the US GEER Team members was provided by the U.S. National Science Foundation (NSF) as part of the Geotechnical Extreme Event Reconnaissance (GEER) Association activity through CMMI-1300744 and RAPID grant CMMI-1724575. Any opinions, findings, and conclusions or recommendations expressed in this material are those of the authors and do not necessarily reflect the views of EQC, the National Science Foundation, or the host institutions of the authors.

The authors would like to acknowledge the assistance of the wider NZ and US GEER team as well as the many practicing engineers who participated in the different aspects of the postearthquake reconnaissance. Their contributions are reflected in papers within this special issue, as well as on the GEER website at http://www.geerassociation.org./. We acknowledge the New Zealand GeoNet project and its sponsors EQC, GNS Science and LINZ, for providing ground motion records used in this publication. We acknowledge the New Zealand Geotechnical Database for the use of CPT data in this paper.

Finally, we would like to thank Simon Cox for his constructive comments during the review of this paper.

\section{REFERENCES}

1 Bradley BA, Razafindrakoto HNT and Nazer MA (2017). "Strong ground motion observations of engineering interest from the 14 November 2016 Mw7.8 Kaikoura, New Zealand earthquake". Bulletin of the New Zealand Society for Earthquake Engineering, 50(2): 85-93.

2 Dellow S, Massey C, Cox S, Archibald G, Begg J, Bruce Z, Carey J, Davidson J, Della Pasqua F, Glassey P, Hill M, Jones K, Lyndsell B, Lukovic B, McColl S, Rattenbury M, Read S, Rosser B, Singeisen C, Townsend D, Villamor P, Villeneuve M, Godt J, Jibson R, Allstadt K, Rengers F, Wartman J, Rathje E, Sitar N, Adda A-Z, Manousakis J and Little M (2017). "Landslides caused by the 14 November 2016 Mw7.8 Kaikōura earthquake and the immediate response". Bulletin of the New Zealand Society for Earthquake Engineering, 50(2): 106-116.

3 Stirling MW, Litchfield NJ, Villamor P, Van Dissen RJ, Nicol A, Pettinga J, Barnes P, Langridge RM, Little T, Barrell DJA, Mountjoy J, Ries WF, Rowland J, Fenton C, Hamling I, Asher C, Barrier A, Benson A, Bischoff A, Borella J, Carne R, Cochran UA, Cockroft M, Cox SC, Duke G, Fenton F, Gasston C, Grimshaw C, Hale D, Hall B, Hao KX, Hatem A, Hemphill-Haley M, Heron DW, Howarth J, Juniper Z, Kane T, Kearse J, Khajavi N, Lamarche G, Lawson S, Lukovic B, Madugo C, Manousakis I, McColl S, Noble D, Pedley K, Sauer K, Stahl T, Strong DT, Townsend DB, Toy V, Villeneuve M, 
Wandres A, Williams J, Woelz S and Zinke R (2017). "The Mw7.8 2016 Kaikōura earthquake: Surface fault rupture and seismic hazard context" Bulletin of the New Zealand Society for Earthquake Engineering, 50(2): 7384.

4 Cubrinovski M, Bray JD, de la Torre C, Olsen MJ, Bradley BA, Chiaro G, Stocks E and Wotherspoon L (2017). "Liquefaction effects and associated damages observed at the Wellington Centreport from the 2016 Kaikoura earthquake". Bulletin of the New Zealand Society for Earthquake Engineering, 50(2): 152-173.

5 Pettinga JR, Yetton MD, Van Dissen RJ, Downes G (2001). "Earthquake Source Identification and Characterisation for the Canterbury Region, South Island, New Zealand". Bulletin of the New Zealand Society for Earthquake Engineering 34: 282-317.

6 Grapes RH, Little TA and Downes GL (1998). "Rupturing of the Awatere Fault during the 1848 October 16 Marlborough earthquake, New Zealand: historical and present day evidence". New Zealand Journal of Geology and Geophysics, 41: 387-399.

7 Mason DPM and Little TA (2006). "Refined slip distribution and moment magnitude of the 1848 Marlborough earthquake, Awatere Fault, New Zealand". New Zealand Journal of Geology and Geophysics, 49: 375-382.

8 Cowan HA (1991). "The North Canterbury earthquake of September 1, 1888". Journal of the Royal Society of New Zealand, 21(1): 1-12.

9 Downes G and Yetton M (2012). "Pre-2010 historical seismicity near Christchurch, New Zealand: The $1869 \mathrm{Mw}$ 4.7-4.9 Christchurch and 1870 Mw 5.6-5.8 Lake Ellesmere earthquakes". New Zealand Journal of Geology and Geophysics, 55(3): 199-205.

10 van Dissen, R, McSaveney M, Townsend D, Hancox G, Little TA, Ries W, Perrin N, Archibald G, Dellow G, Massey C and Misra S (2013). "Landslides and Liquefaction generated by the Cook Strait and Lake Grassmere Earthquakes: A Reconnaissance Report". Bulletin of the New Zealand Society for Earthquake Engineering, 46(4): 196-200.

11 Statistics NZ (2013). "Number of Electorates and Electoral Populations: 2013 Census". Statistics NZ. ISBN 978-0-478-40854-6.

12 Marlborough Catchment Board (1959). "Wairau Valley Scheme: scheme and economic reports". Marlborough Catchment Board. Blenheim.

13 Brown LJ and Weeber JH (1992). "Geology of the Christchurch Urban Area". Institute of Geological and Nuclear Sciences.

14 Standards New Zealand (2004). "NZS1170.5 Earthquake actions". Wellington, NZ.

15 Bradley BA (2014) "Site-specific and spatially-distributed ground-motion intensity estimation in the 2010-2011 Canterbury earthquakes". Soil Dynamics and Earthquake Engineering, (61-62): 83-91.

16 Cubrinovski M, Green R, Allen J, Ashford S, Bowman E, Bradley BA, Cox B, Hutchinson T, Kavazanjian E, Orense R, Pender M, Quigley M and Wotherspoon L (2010). "Geotechnical reconnaissance of the 2010 Darfield (New
Zealand) earthquake". Bulletin of the New Zealand Society of Earthquake Engineering, 43(4): 243-321.

17 Cubrinovski M, Bradley BA, Wotherspoon L, Green RA, Bray JD, Wood C, Pender M, Allen J, Bradshaw A, Rix G, Taylor M, Robinson K, Henderson D, Giorgini S, Ma K, Winkley A, Zupan J, O'Rourke T, DePascale G and Wells D (2011). "Geotechnical aspects of the 22 February 2011 Christchurch Earthquake". Bulletin of the New Zealand Society of Earthquake Engineering, 44(4): 205-226.

18 Arnold $\mathrm{T}$ (1847). "Letters from New Zealand and Tasmania”, 1847-50, p.83. ATL.

19 Thompson AS (1859). "The Story of New Zealand: Past and Present - Savage and Civilised". Vol. 2. John Murray, London.

20 Marlborough District Council (2017). "Smart Maps". https://maps.marlborough.govt.nz/smartmaps, Accessed January 2017.

21 ASTM (2007). "Standard Test Method for Particle-Size Analysis of Soils". ASTM International, West Conshohocken, PA, 2011.

22 Cook J (1895). "Map of Cloudy Bay Survey District". Department of Lands and Survey.

23 Dizhur D, Simkin G, Giaretton M, Loporcaro G, Palermo A and Ingham J (2017). "Performance of winery facilities during the 14 November 2016 Kaikōura earthquake". Bulletin of the New Zealand Society for Earthquake Engineering, 50(2): 206-224.

24 Wotherspoon LM, Bradshaw A, Green R, Wood C, Palermo A, Cubrinovski M and Bradley, BA (2011). "Performance of bridges during the 2010 Darfield and 2011 Christchurch earthquakes". Seismological Research Letters, 82(6): 950-964.

25 Rattenbury MS, Townsend DB and Johnston MR (Compilers) (2006). "Geology of the Kaikōura Area. Institute of Geological \& Nuclear Sciences 1:250 000 Geological Map 13". 1 sheet + 70p. Lower Hutt, New Zealand. GNS Science.

26 New Zealand Geotechnical Database (NZGD) (2017). "New Zealand Geotechnical Database". https://www.nzgd.org.nz (Accessed January 2017).

27 ASTM (2011). "Standard Practice for Classification of Soils for Engineering Purposes (Unified Soil Classification System)". ASTM International, West Conshohocken, PA, 2011.

28 Haskell JJM, Madabhushi SPG, Cubrinovski $M$ and Winkley A (2013) "Lateral spreading-induced abutment rotation in the 2011 Christchurch earthquake: Observations and analysis". Geotechnique, 63(15): 13101327.

29 Rother H (1996). "Late Pleistocene Glacial Geology of the Hope-Waiau Valley System in North Canterbury, New Zealand". PhD Thesis, University of Canterbury. 330 pp.

30 Palermo A, Liu R, Rais A, McHaffie B, Andisheh K, Pampanin S, Gentile R, Nuzzo I, Granerio M, Loporcaro G, McGann C and Wotherspoon LM (2017). "Performance of road bridges during the 14 November 2016 Kaikoura earthquake". Bulletin of the New Zealand Society for Earthquake Engineering, 50(2): 253-270.

31 Cox S (2017). Personal Communication. April 2017. 